INSTITUTO DE CIÊNCIAS BIOLÓGICAS

DEPARTAMENTO DE BOTÂNICA MESTRADO EM BOTÂNICA

\title{
O gênero Peperomia da Ilha da Trindade: um caso de isolamento?
}

\author{
Tamara Silva Dantas
}

Orientadora: Micheline Carvalho Silva 
INSTITUTO DE CIÊNCIAS BIOLÓGICAS

DEPARTAMENTO DE BOTÂNICA

MESTRADO EM BOTÂNICA

\title{
O gênero Peperomia Ruiz da Ilha da Trindade: um caso de isolamento?
}

\author{
Tamara Silva Dantas
}

Dissertação apresentada ao Programa de Pós-graduação em Botânica como requisito para obtenção do título de Mestre em Botânica, junto ao Departamento de Botânica do Instituto de Ciências Biológicas da Universidade de Brasília.

Brasília-DF, janeiro de 2015. 


\section{O gênero Peperomia da Ilha da Trindade: um caso de isolamento?}

\section{Tamara Silva Dantas}

Dissertação apresentada ao Programa de Pós-graduação em Botânica como requisito para obtenção do título de Mestre em Botânica, junto ao Departamento de Botânica do Instituto de Ciências Biológicas da Universidade de Brasília.

Aprovada em:

Dra. Micheline Carvalho Silva (Orientadora)

Universidade de Brasília - UnB

Adriana Quintella Lobão (Membro Externo)

Universidade Federal Fluminense - UFF

Dr. Marcelo Fragomeni Simon (Titular)

Universidade de Brasília - UnB

Cássia Beatriz Rodrigues Munhoz (Suplente)

Universidade de Brasília - UnB 


\section{Agradecimentos}

A minha família e aos amigos, que não estão envolvidos com o meio científico, mas que me apoiam e incentivam em todos os momentos.

A minha orientadora e amiga Micheline, pela paciência, dedicação, apoio e incentivo, sem ela não seria possível estar aqui hoje.

Ao professor e amigo Paulo, pelo apoio, oportunidades e pela presença durante o desenvolvimento deste estudo.

A todos os amigos da UnB e do laboratório por todos os momentos de alegria e pela ajuda de sempre.

À Josemília e à Marina pelo auxílio com os empréstimos.

À Marinha do Brasil pelo apoio logísico, aos tripulantes do "NaPaOc Amazonas" e aos militares que guarnecem a Ilha da Trindade.

Ao Cnpq pela bolsa concedida. 


\section{ÍNDICE}

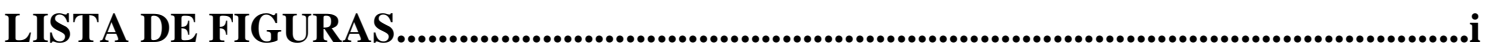

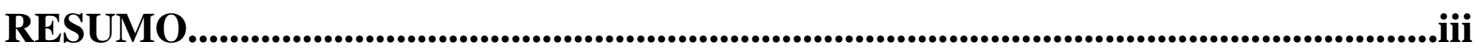

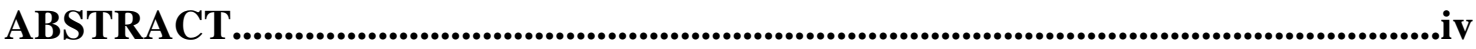

INTRODUÇÃ

REFERÊNCIA BIBLIOGRÁFICA GERAL ........................................................................4

CAPÍTUlO I: O gênero Peperomia Ruiz \& Pav. (Piperaceae) da Ilha da Trindade, Brasil: um caso de isolamento? ..............................................................................6

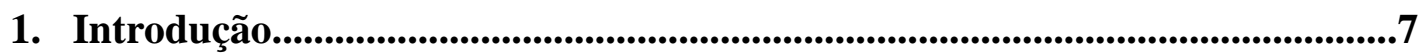

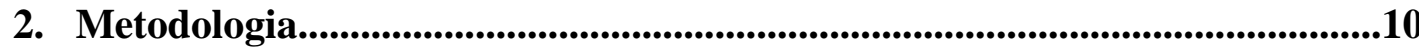

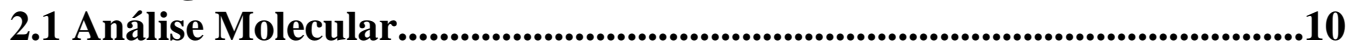

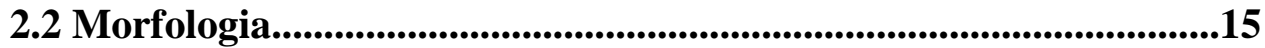

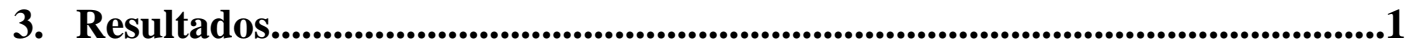

3.1 Análises Moleculares..........................................................................................16

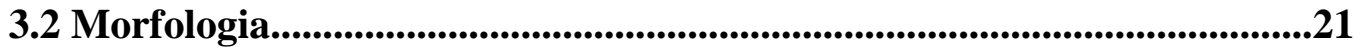

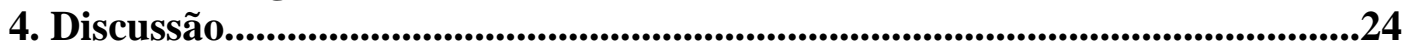

5. Referências Bibliográficas..................................................................................28

CAPÍTULO II:Peperomia sp. (Piperaceae), uma nova espécie da Ilha da Trindade,

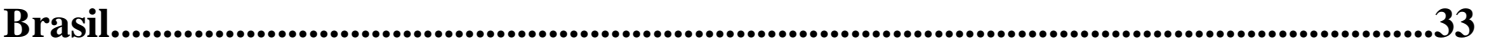

1. Introdução.............................................................................................................34

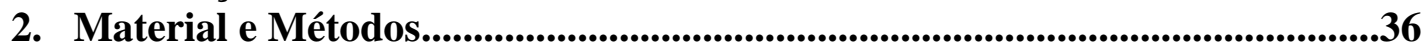

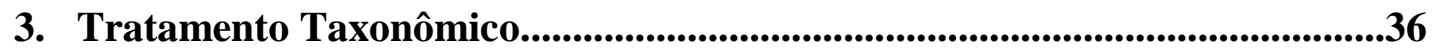

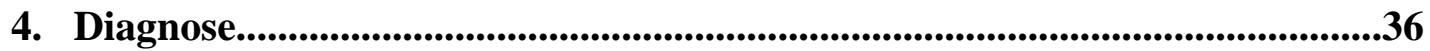

5. Descrição........................................................................................................................36

6. Distribuição Geográfica e Ecologia...............................................................39

7. Espécimes adicionais examinados..................................................................40

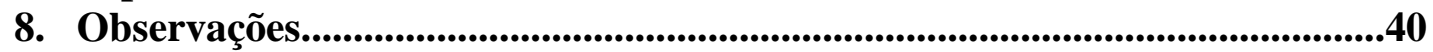

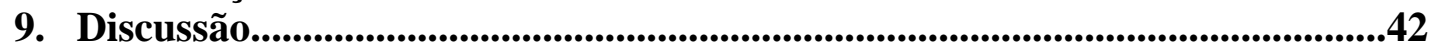

10. Referências Bibliográficas.....................................................................................44

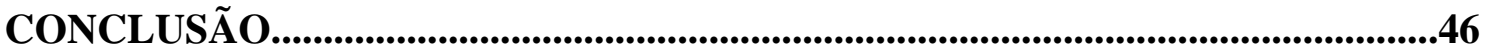

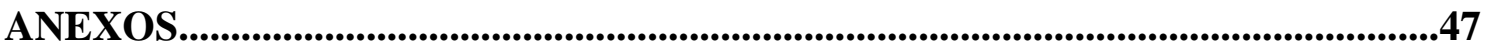




\section{LISTA DE FIGURAS}

CAPÍTUlO I: O gênero Peperomia Ruiz \& Pav. (Piperaceae) na Ilha da Trindade, Brasil: um caso de isolamento?

Figura 1. Ocorrência de Peperomia glabella no Brasil. A - P. glabella; B - P. glabella var. nervulosa; $\mathrm{C}-P$. glabella var. nigropunctata; D - P. glabella var. nudipetiolata.

Figura 2. Matriz alinhada trnK/matK. Em destaque a transversão de $\mathrm{C}$ para $\mathrm{A}$ na posição 34 que ocorre apenas em $P$. sp. Entre parênteses estão as localidades dos espécimes, os que não possuem são sequências obtidas do GenBank.

Figura 3. Matriz alinhada trnK/matK. Em destaque a inserção de 19 pares de bases que ocorre apenas em $P$. sp. Entre parênteses estão as localidades dos espécimes, os que não possuem são sequências obtidas do GenBank.

Figura 4. Árvore consenso de Máxima Verossimilhança (MV) do trnK/matK, mostrando as $P$. glabella e as $P$. sp. Os números próximos aos ramos são os valores de bootstrap para Máxima Parcimônia e Máxima Verossimilhança, e probabilidades posteriores para Bayesiana, respectivamente.

Figura 5. Árvore consenso de Análise Bayesiana (B) do espaçador ITS, mostrando as P. glabella do continente e as Peperomia de Trindade. Os números próximos aos ramos são os valores de bootstrap para Máxima Parcimônia e Máxima Verossimilhança, e probabilidades posteriores para Bayesiana, respectivamente.

Figura 6. Localização da Ilha da Trindade, em destaque a Floresta de Samambaias Gigantes.

Figura 7. Hábito, filotaxia e tamanho dos entrenós de $P$. glabella e $P$. sp. A - Hábito de Peperomia glabella; B - Hábito de P. sp. ; C - entrenós de Peperomia glabella; D entrenós de $P$. sp.

Figura 8. Anteras de $P$. sp. e $P$. glabella. A. $P$. sp. com a presença de glândulas negras nas anteras. B. P. glabella sem glândulas negras nas anteras. (Vouchers: A- Dantas 110 - UB; B- Raimundo S. P. 1030 - RB).

Figura 9. Análise de componentes principais. P. glabella em preto; P. glabella var. glabella em rosa; $P$. glabella var. nervulosa em verde; $P$. glabella var. nigropunctata 
em amarelo; P. glabella var. nudipetiolata em azul claro; $P$. glabella da Ilha da Trindade em vermelho.

CAPÍTULO II: Peperomia sp. (Piperaceae), uma nova espécie da Ilha da Trindade, Brasil.

Figura 1. a - g: Peperomia sp. T.S. Dantas, M. Carvalho-Silva e P.S. Câmara. a. hábito. b. base da folha, face adaxial. c. ápice da folha, face adaxial. d. Pecíolo com tricomas esparsos. e. Detalhe da espádice. f. Fruto globoso evidenciando ápice com rostro curto. g. Vista frontal da antera com glândulas negras.

Figura 2. Localização da Ilha da Trindade, em destaque localização da "floresta de samambaias gigantes" encontrada somente em altitudes elevadas.

Figura 3. A - C. Peperomia sp. A e B. Hábito terrestre. C. Ocorrência debaixo das samambaias gigantes. 


\section{RESUMO}

Peperomia é um dos maiores gêneros das angiospermas basais, com aproximadamente 1.600 espécies, distribuídas pantropicalmente. A Ilha da Trindade é uma ilha oceânica brasileira localizada a $1.200 \mathrm{~km}$ da costa do Brasil que emergiu a cerca de 3 milhões de anos da zona abissal no Atlântico Sul. A Ilha possui uma área de 9,28 km² e altitude máxima de 620 metros onde ocorre uma floresta nebular, a floresta de samambaias. São registradas na Ilha da Trindade duas espécies de Peperomia: P. beckeri, endêmica e conhecida apenas pelo tipo, e P. glabella. Espécimes de $P$. glabella da ilha da Trindade e de $P$. glabella que ocorre no continente foram analisados com o objetivo de investigar se a Peperomia que ocorre em Trindadeé uma espécie nova e endêmica ou uma variação morfológica de P. glabella que ocorre no continente. Foram utilizados materiais oriundos de 22 herbários além de materiais coletados na Ilha da Trindade, na Bahia e no Rio de Janeiro. Foram amplificados o gene matk e o espaçador ITS para análises filogenéticas e moleculares, além de análises morfológicas comparativas entre $P$. glabella e suas variedades e a Peperomia que ocorre em Trindade. Foram encontradas diferenças genéticas e morfológicas significativas entre P. glabella e a Peperomia que ocorre em Trindade e uma nova espécie foi descrita para a Ilha da Trindade. Peperomia beckeri não foi reencontrada e foi analisado apenas o material desta espécie. Materialtipo das variedades que ocorrem no Brasil foram analisados e propõe-se novos sinônimos.

Palavra-chave: filogenia, matk, ITS, morfologia, nova espécie, taxonomia. 


\section{ABSTRACT}

Peperomia is one of the largest genera of basal angiosperms with about 1,600 species pantropically distributed. Trindade is a Brazilian oceanic island located about 1,200 km of the coast Brazilian, that emerged about 3 million years of abyssal zone in the South Atlantic, has a maximum altitude of 620 meters and an area of $9.28 \mathrm{~km}^{2}$. Are registered in the Trindade Island the occurrence of two species of Peperomia: P. beckeri, endemic and known only by the type and P. glabella. The aims of this study were know whether the Peperomia occurring in Trindade is a new species and endemic species or morphological variation of $P$. glabella. We used the matk gene and the spacer ITS for phylogenetic and molecular analysis, and comparative morphological analysis between P. glabella and varieties and Peperomia occurring in Trindade Island. Genetic and morphological significant differences were observed between $P$. glabella and Peperomia occurring in Trindade. The Peperomia from the Trindade island is a different species of $P$. glabella and P. beckeri, according to the description of the authors of the species. Therefore, the Peperomia occurring in the Trindade Island is a new and endemic species of this site.

Key word: phylogeny, matK gene, ITS spacer, morphology, new species, taxonomy 


\section{INTRODUÇÃO}

Trindade é uma ilha oceânica brasileira localizada a cerca de $1.200 \mathrm{~km}$ da costa brasileira no Atlântico Sul, nas coordenadas 20³1'30' 'S e 29¹9'30'’W. A Ilha possui $9,28 \mathrm{~km}^{2}$ de superfície e a profundidade ao redor da ilha é estimada entre 5.500 e 5.800 m, sendo o ponto de maior altitude com 620 m (Serafini et al. 2010; Alves 1998). O clima é do tipo oceânico tropical com temperatura média anual de $25,2^{\circ} \mathrm{C}$. A Ilha é resultado da atividade vulcânica da zona abissal do atlântico há cerca de três milhões de anos e faz parte de uma grande cadeia vulcânica submarina chamada lineamento Vitória-Trindade (Alves 1998; Almeida 2000; Duarte et al. 2012). Trindade é constituída, quase que inteiramente, de rochas vulcânicas e seu relevo é extremamente acidentado.

O descobrimento da Ilha da Trindade, ainda hoje, é motivo de dúvida. Alguns historiadores atribuem o descobrimento da Ilha ao navegador espanhol João da Nova que, viajando a serviço de Portugal, teria descoberto Trindade em 1501. No entanto, outros historiadores afirmam que o descobridor foi Estêvão da Gama em 1502, durante a segunda viagem de Vasco da Gama às Índias, e neste momento a Ilha foi batizada de Ilha da Santíssima Trindade (Gusmão 2005).

Entre 1700 e 1926 Trindade foi ocupada e desocupada várias vezes. Cabras, porcos e cães foram deixados no local, sendo que, as cabras, particularmente, obtiveram sucesso e sua população aumentou, destruindo boa parte da vegetação original (Silva \& Alves 2011). Também houve a destruição da vegetação arbórea para plantar alimentos e o extrativismo da madeira de Colubrina glandulosa G. Perkins, confundida na época, com o pau-brasil. O Brasil tomou posse da ilha e em 1957 foi dado início à criação do Posto Oceanográfico da Ilha da Trindade (POIT) e desde então permanece ocupada pela Marinha do Brasil (Gusmão 2005) e estudos científicos vem sendo realizados desde então na Ilha.

A colonização da Ilha e a introdução de animais exóticos ao longo dos anos teve um grande impacto sobre a vegetação. Em 1990 a Marinha do Brasil iniciou o processo de eliminação da população de cabras que estavam causando danos ecológicos, mas só foram eliminadas completamente em 2005. Após a erradicação dos animais já é 
perceptível o aumento da cobertura vegetal, do número de aves marinhas e do volume de água doce dos riachos (Silva \& Alves 2011).

Poucas são as informações sobre a vegetação da Ilha da Trindade antes da ocupação de 1957. Acredita-se que $85 \%$ da Ilha era coberta por florestas de Colubrina glandulosa e que a quase ausência desta planta nas florestas atuais decorreu, além da atividade antrópica, da predação altamente seletiva das cabras (Alves 1998). Atualmente $60 \%$ da ilha é coberta por vegetação herbácea e menos de $5 \%$ é coberta por vegetação de floresta, que é composta especialmente pela samambaia endêmica Cyathea copelandii Kuhn \& Luerss. e alguns representantes de Colubrina glandulosa formando a "floresta nebular de samambaias gigantes" (Alves 1998; Silva \& Alves 2011).

O primeiro levantamento da vegetação da ilha foi realizado em 1998, onde foram encontradas 113 espécies de plantas vasculares (Alves 1998). Mais recentemente, Faria et al. (2012) fizeram o levantamento de briófitas e encontraram 32 espécies. O número de espécies vegetais pode ser considerado pequeno, porém o que chama a atenção não é a diversidade, e sim o número de espécies endêmicas, sendo encontradas na Ilha nove espécies de plantas vasculares endêmicas (Alves 1998). Considerando o levantamento de briófitas, nenhuma espécie endêmica foi encontrada. Um dos gêneros encontrados em Trindade é Peperomia, sendo registradas duas espécies.

Peperomia é um dos maiores gêneros das angiospermas basais, sendo aceitas entre 1.500 e 1.700 espécies (Wanke et al. 2006). É o segundo maior gênero, em número de espécies, da família Piperaceae e é distribuído pantropicalmente, sendo que 90\% das espécies ocorrem no neotrópico. São espécies predominantemente epífitas, mas podem ser encontradas em fendas de rochas ou no solo, e ocorrem preferencialmente em locais úmidos e sombreados, sendo menos frequente em matas secas e vegetações campestres (Carvalho-Silva 2008).

Os caules deste gênero são suculentos, principalmente de cor verde, e os ramos geralmente são cilíndricos. A filotaxia pode ser oposta, oposta-cruzada, alterna ou verticilada e as folhas são sempre simples, inteiras, geralmente pecioladas, suculentas, planas ou conduplicadas. Os pecíolos são cilíndricos e as nervuras foliares são conspícuas ou inconspícuas, variando entre branca, verde a vinácea. As inflorescências são frequentemente espádices e estão em posição terminal, axilar ou oposta à folha, são retas ou curvadas e o comprimento varia de 1 a 13 centímetros (Carvalho-Silva 2008). 
No Brasil são aceitas 166 espécies de Peperomia, sendo 103 endêmicas (Guimarães et al. 2014). Para a Ilha da Trindade são registradas duas espécies de Peperomia: Peperomia beckeri, considerada endêmica e conhecida apenas pelo material tipo, que se encontra no Museu Nacional (R) e Peperomia glabella (Sw.) A. Dietr.com as variedades $P$. glabella var. glabella (Sw.) A. Dietr. e P. glabella var. nigropunctata (Miq.) Dahlst. (Alves \& Guimarães 1998).

Wanke et al. (2006) estudando as relações filogenéticas no gênero Peperomia, utilizaram o gene matK e provaram a monofilia do grupo. Em 2007, Wanke e colaboradores investigaram a evolução da região $t r n K / m a t K$ em Piperales e as relações filogenéticas entre os gêneros das Piperaceae. Em ambos os trabalhos a região trabalhada do matK, apresentou uma notável taxa de heterogeneidade, particularmente alta em Peperomia, gerando árvores internamente bem resolvidas para este gênero. Samain et al. (2009) agregaram dados moleculares e morfológicos para explicar a evolução deste gênero e obtiveram resultados congruentes na maior parte do estudo.

Já foram realizados alguns estudos com o gênero Peperomia em ilhas oceânicas, baseados em características morfológicas. Valdebenito et al. (1990) estudaram a morfologia de Peperomia berteroana Miq. da Ilha de Juan Fernandez (Ilha do Oceano Pacífico) e estudando Peperomia tristanensis Christoph. da Ilha de Tristão da Cunha (Ilha do Oceano Atlântico) concluíram que, apesar de haver diferenças entre elas, os táxons estudados devem ser tratados como subespécies (P. berteroana (Miq.) subsp. berteroana e P. berteroana (Miq.) subsp. Tristanensis (Christoph.) Valdebenito) e não como espécies distintas. Valdebenito et al. (1992) estudaram quatro espécies de Peperomia que ocorrem em Juan Fernandez (P. berteroana (Miq.), P. margaritifera Bertero ex Hook, P. skottsbergii C. DC. ex Skottsb. e P. fernandeziana Miq.) e concluíram que $P$. berteroana, $P$. margaritifera, $P$. skottsbergii são endêmicas e que o ancestral delas foi introduzido na ilha em época diferente de P. fernandeziana, que ocorre também no continente.

Observações preliminares sugerem que a $P$. glabella que ocorre na Ilha da Trindade é morfologicamente diferente da $P$. glabella que ocorre no continente. Por se tratar de uma ilha oceânica, onde há um alto nível de endemismo devido ao isolamento geográfico, é possível que a $P$. glabella ocorre em Trindade seja um táxon novo e endêmico. Portanto, os objetivos deste estudo são: esclarecer se a P.glabella que ocorre 
na Ilha da Trindade é um táxon novo e endêmico desta região, ou se é apenas uma variação morfológica de Peperomia glabella, e suas variedades, que ocorrem no continente e esclarecer a origem do fundador da população de Peperomia, que atualmente ocorre em Trindade.

\section{REFERÊNCIA BIBLIOGRÁFICA GERAL}

Almeida,F.F.M. 2000. A Ilha da Trindade. In: Schobbenhaus,C.; Campos,D.A.;Queiroz,E.T./ Winge,M.; Berbert-Born,M. (Edit) Sítios Geológicos $e$ Paleontológicos do Brasil. Atualmente em http://sigep.cprm.gov.br/sitio092/sitio092.htm

Alves, R.J.V. 1998. Ilha da Trindade e Arquipélago Martin Vaz - Um Ensaio Geobotânico. Serviço de Documentação. Marinha do Brasil Rio de Janeiro. Diretoria de Hidrografia e Navegação.

Alves, R.J.V \& Guimarães, E.F. 1998. Piperaceae da Ilha da Trindade Bradea 8(17): 97100.

Carvalho-Silva, M. Peperomia Ruiz \& Pav. no Brasil: morfologia e taxonomia do subgênero Rhynchophorum (Miq.) Dahlst. Tese de Doutorado, Instituto de Pesquisas Jardim Botânico do Rio de Janeiro Escola Nacional de Botânica Tropical (2008).

Duarte, Regina Horta; Horta, Güydo Campos Machado Marques. 2012. Barth e a ilha da Trindade, 1957-1959. História, Ciências, Saúde - Manguinhos, Rio de Janeiro, v.19, n.3, jul.-set. p.951-968.

Faria, A. L. A.; Carvalho-Silva, M.; Costa, D.P. \& Câmara, P. E.A.S. 2012. The bryophytes of Trindade Island, South Atlantic, Brazil.Acta Bot. Bras. vol.26, n.4, pp. 785-795.

Guimarães, E.F.; Carvalho-Silva, M.; Monteiro, D.; Medeiros, E.S. 2014. Piperaceae in Lista de Espécies da Flora do Brasil. Jardim Botânico do Rio de Janeiro. Disponível em: <http://floradobrasil.jbrj.gov.br/jabot/floradobrasil/FB12609>. Acesso em: 20 Dez. 2014

Gusmão, L. G. S. 2005. Ilha da Trindade e Arquipélago Martin Vaz. In: Geografia : ensino fundamental e ensino médio : o mar no espaço geográfico brasileiro / coordenação Carlos Frederico Simões Serafim, organização Paulo de Tarso Chaves. - Brasília : Ministério da Educação, Secretaria de Educação Básica, 2005. 304 p. (Coleção explorando o ensino , v. 8).

Samain, M.S., Vanderschaeve, L., Chaerle, P., Goetghebeur, P., Neinhuis, C. \& Wanke, S. 2009. Is morphology telling the truth about the evolution of the species rich genus Peperomia (Piperaceae)? Plant Systematics and Evolution, 278,1-21.

Serafini, T.Z.; França, G.B.D. \& Andriguetto-filho, J.M. 2010. Ilhas oceânicas brasileiras: biodiversidade conhecida e sua relação com o histórico de uso e ocupação humana. Journal of Integrated Coastal Zone Management 10(3): 281301. 
Silva, N.G. \& Alves, R.J.V. 2011. The eradication of feral goats and its impacto in plant biodiversity - a milestome in the history of Trindade Island, Brazil. Rodriguesia 62(3): 717-719.

Valdebenito, H., Stuessy, T.F \& Crawford, D. J. 1990. Synonyny in Peperomia berteroana (Piperaceae) results in biological disjunction between Pacific and Atlantic Oceans. Brittonia, 42, 121-4.

Valdebenito, H., Stuessy, T.F, Crawford, D. J. \& Silva O.M. 1992. Evolution of Peperomia (Piperaceae) in the Juan Fernandez Islands, Chile. Plant Systematics and Evolution, 182, 107-19.

Wanke, S.; Jaramillo, M.A.; Borsch, T.; Samain, M.S.; Quandt, D. \& Neinhuis, C. 2007. Evolution of the Piperales - matK and trnK intron sequence data reveal lineage specific resolution contrast. Molecular Phylogenetics and Evolution 42: 477-497.

Wanke, S., Samain, M.S., Vanderschaeve, L., Mathieu, G., Goetghebeur, P. \& Neinhuis, C. 2006. Phylogeny of the genus Peperomia (Piperaceae) inferred from the trnK/matK region (cpDNA). Plant Biology 8: 93-102. 


\section{CAPÍTULO I}

O gênero Peperomia Ruiz \& Pav. (Piperaceae) na Ilha da Trindade, Brasil: um caso de isolamento? 


\title{
O gênero Peperomia Ruiz \& Pav. (Piperaceae) na Ilha da Trindade, Brasil: um caso de isolamento?
}

\author{
Tamara Silva Dantas ${ }^{1}$, Paulo E. A. S. Câmara ${ }^{1}$ e Micheline Carvalho Silva1 \\ ${ }^{1}$ Universidade de Brasília, Instituto de Ciências Biológicas, Departamento de Botânica
}

\section{Introdução}

Peperomia Ruiz \& Pav. compreende ca. de 1600 espécies e está entre os 20 maiores gêneros de angiospermas com maior número de espécies (Frodin 2004). O gênero possui distribuição pantropical (Wanke et al. 2006) e 90\% das espécies ocorrem no neotrópico (Carvalho-Silva 2008). No Brasil, são aceitas 166 espécies de Peperomia, sendo que 103 são endêmicas. As espécies são encontradas nas cinco regiões brasileiras, nos domínios fitogeográficos da Amazônia, Caatinga, Cerrado e Mata Atlântica (Guimarães et al. 2014).

Peperomia são ervas predominantemente epífitas, mas podem ser encontradas em fendas de rochas ou no solo, e ocorrem preferencialmente em locais úmidos e sombreados (Symmank et al. 2011). São plantas de folhas suculentas, alternas, verticiladas ou opostas e inflorescências em espádices com flores aperiantadas com dois estames, um ovário, um óvulo, um lóculo e estigma único (Yuncker 1974).

Wanke et al. $(2006,2007)$ realizando estudos filogenéticos em Peperomia com o gene matK e o íntron trnK, mostraram o gênero Peperomia como monofilético. Nos estudos sobre as relações filogenéticas do gênero realizados por Wanke et al. (2006), foram apresentados oito clados bem suportados. Os autores incluíram a espécie Peperomia glabella (Sw.) A. Dietr. no clado nomeado Sphaerocarpidium. Este clado é composto pelas espécies do subgênero Sphaerocarpidium (Dahlst.) sensu Dahlstedt (1900).

Samain et al. (2009) agregaram dados moleculares e morfológicos para tentar explicar a evolução de Peperomia e utilizaram o gene matK e o íntron $\operatorname{trn} K$ de cloroplasto, e acrescentaram o espaçador nuclear ITS (Internal Transcribed Spacer) e o 26S. Os autores apresentaram 10 clados, alguns deles semelhantes aos obtidos por Wanke et al. (2006). O clado nomeado Sphaerocarpidium por Wanke et al. (2006) foi 
tratado por Samain et al. (2009) como clado Micropiper, já que Peperomia subg. Micropiper (Miq.) Miq. havia sido nomeado erroneamente por Dalhstedt (1990). Mesmo com a adição de novos marcadores o clado permaneceu com a mesma circunscrição.

Peperomia glabella é encontrada na região neotropical, desde o sul da Flórida (EUA) até o Brasil (USDA 2015). No Brasil possui representantes na Mata Atlântica, desde Pernambuco ao Rio Grande do Sul e poucos representantes na Amazônia nos estados do Pará, Roraima, Rondônia Acre e Amapá (figura 1). São reconhecidas nove variedades para o mundo, sendo três para o Brasil: Peperomia glabella var. glabella (Sw.) A. Dietr., P. glabella var. nervulosa (C. DC.) Yunck. e P. glabella var. nigropuntata (Miq.) Dahlst. Apesar de não ser citada para o Brasil P. glabella var. nudipetiolata Trel. \& Yunck. também foi encontrada entre o material analisado neste trabalho. Segundo Yuncker (1974) P. glabella var. glabella são plantas menores com formato da folha ovada ou mais comumente ovada-elíptica-lanceolada, pecíolo ciliado, comprimento da folha entre 1,5 e 3,5 cm e largura entre 0,8 e $1,3 \mathrm{~cm}$. As duas extremidades são de agudas à acuminadas e possuem cílios perto do ápice. P. glabella var. nervulosa possui folhas lanceoladas, com ambas extremidades de aguda á longoacuminada. O comprimento varia de 3 a $8 \mathrm{~cm}$ e a largura de $1 \mathrm{a} 3 \mathrm{~cm}$., P. glabella var. nigropunctata possui pontos pretos (glândulas) em todas as partes, exceto nas anteras, com formato das folhas podendo ser: elíptico-lanceolado, subovado, elíptico-obovado ou subrômbico. $\mathrm{O}$ ápice de agudo à acuminado com alguns tricomas. $\mathrm{O}$ comprimento varia de 3,5 a $7 \mathrm{~cm}$ e a largura de 2 a $3 \mathrm{~cm}$. O pecíolo é canaliculado e glabro. Ainda de acordo com Yuncker (1974), P. glabella var. nervulosa é baseada em plantas grandes com folhas grandes, quando comparadas com P. glabella var. glabela, mas é muito difícil fazer distinção entre estas duas variedades. Já $P$. glabella var. nigropunctata é mais fácil de diferenciar pela completa falta de tricomas no pecíolo. As três variedades brasileiras têm sido separadas pela variação da forma, tamanho das folhas e pilosidade do pecíolo. 

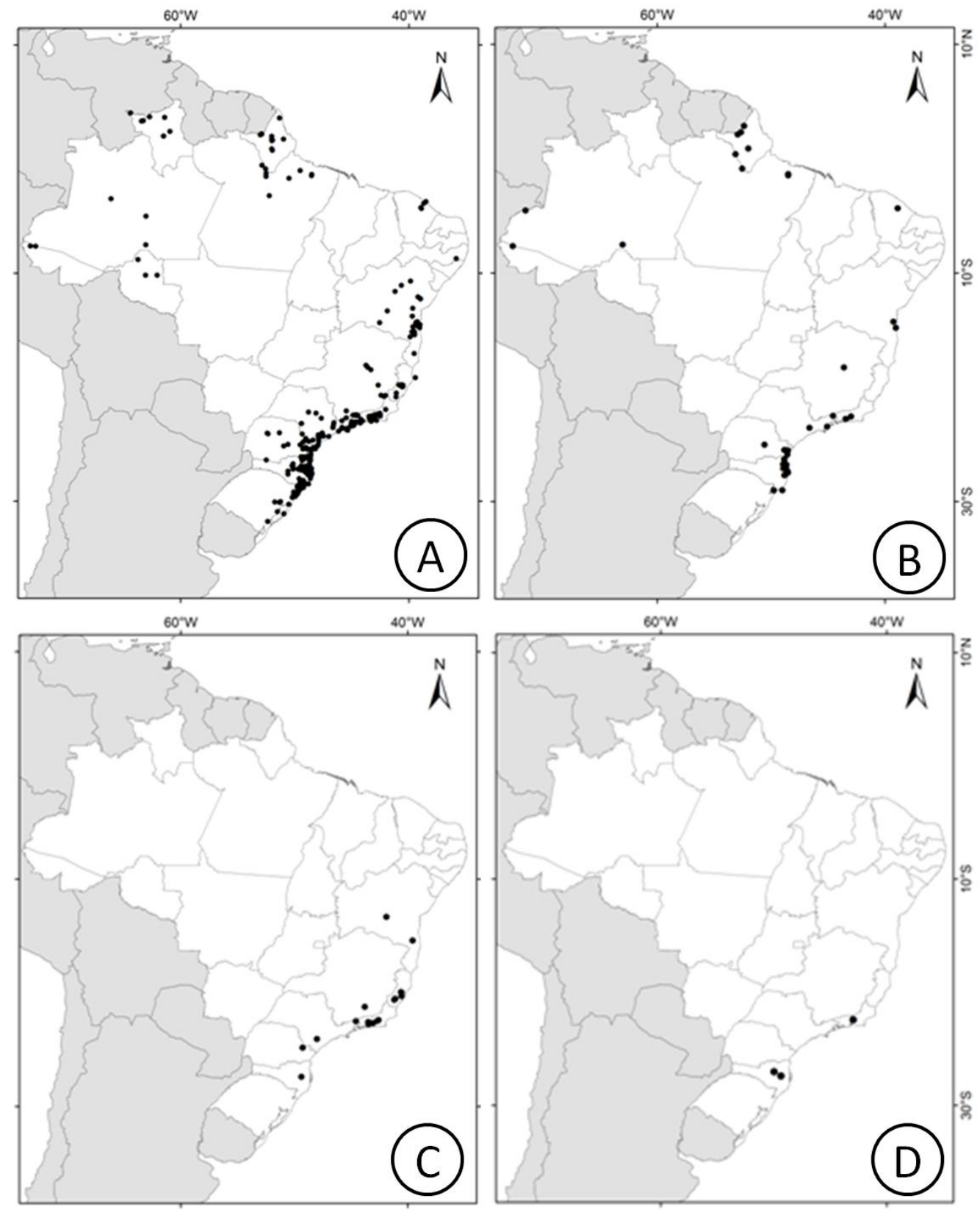

Figura 1. Ocorrência de Peperomia glabella no Brasil. A - P. glabella; B - P. glabella var. nervulosa; $\mathrm{C}-P$. glabella var. nigropunctata; $\mathrm{D}-P$. glabella var. nudipetiolata.

Na Ilha da Trindade, Segundo Alves e Guimarães (1998), são registradas duas espécies de Peperomia: P. glabella var. glabella (Sw.) A. Dietr. e P. glabella var. nigropunctata (Miq.) Dahlst. e Peperomia beckeri E. F. Guim. \& R. J. V. Alves, considerada endêmica, e conhecida apenas pelo holótipo que se encontra no Museu Nacional (herbário R). Atualmente $60 \%$ da ilha é coberta por vegetação herbácea e menos de $5 \%$ é coberta por vegetação de floresta, que é composta especialmente pela samambaia endêmica Cyathea copelandii Kuhn \& Luerssen e alguns representantes de 
Colubrina glandulosa Perkins, formando a "floresta nebular de samambaias gigantes", localizada na maior altitude da Ilha (Alves 1998; Silva \& Alves 2011). Um primeiro levantamento da vegetação da ilha foi realizado por Alves (1998), onde foram encontradas 113 espécies de plantas vasculares das quais nove são endêmicas.

Trindade é uma ilha oceânica localizada cerca de $1.200 \mathrm{~km}$ da costa brasileira no Atlântico Sul, entre $20^{\circ} 31^{\prime} 30^{\prime}$ 'S e $29^{\circ} 19^{\prime} 30^{\prime}$ 'W. A Ilha possui 9,28 km² de superfície (Alves 1998; Serafini et al. 2010), sendo o ponto de maior altitude com $620 \mathrm{~m}$, o Pico do Desejado (Serafini et al. 2010; Alves 1998). A Ilha é resultado de atividade vulcânica há cerca de três milhões de anos e faz parte de uma grande cadeia vulcânica submarina (Alves 1998; Almeida 2000, Duarte et al. 2012). É constituída, quase que inteiramente, de rochas vulcânicas e possui o relevo extremamente acidentado.

É uma ilha oceânica que apresenta um alto nível de endemismo, devido ao isolamento geográfico, com cerca de $10 \%$ das plantas vasculares endêmicas (Alves 1998). Embora os espécimes encontrados na Ilha da Trindade sejam identificados como $P$. glabella, é possível que a $P$. glabella que ocorre em Trindade seja um táxon novo e endêmico, pois observações preliminares sugerem que a $P$. glabella que ocorre na Ilha da Trindade é morfologicamente diferente da P. glabella que ocorre no continente. Sendo assim, a P. glabella da Ilha da Trindade será tratada, neste estudo, como Peperomia sp. A origem da $P$. sp. ainda é desconhecida, estas plantas são próximas morfologicamente $P$. glabella (encontrada no Brasil), com uma possível afinidade com P. fernandopoiana C. DC., espécie africana. Sendo assim, a população fundadora pode ser brasileira ou africana.

Portanto, os objetivos deste estudo são: esclarecer se a P.glabella que ocorre em Trindade é um táxon novo e endêmico desta região, ou se é apenas uma variação morfológica de Peperomia glabella, e suas variedades, que ocorrem no continente e esclarecer a origem do fundador da população de Peperomia, que atualmente ocorre em Trindade.

\section{Metodologia}

\subsection{Análise Molecular}

Para os estudos moleculares foram amostrados 5 espécimes para o trnK/matK e 7 para o ITS de P.sp. e, 12 espécimes para o $m a t K$ e 8 para o ITS de $P$. glabella 
(tabela 1). Para os espécimes do continente foram priorizadas as diversas variações morfológicas de forma a representar as variedades. Foram utilizadas plantas dos estados de Pernambuco, Minas Gerais, Espírito Santo, Santa Catarina, Rio de Janeiro, Rio Grande do Sul e uma sequência de Peperomia glabella do Genbank, esta última sem referência de localidade. Também foi utilizado material de Peperomia fernandopoiana C. DC., espécie africana morfologicamente mais próxima à $P$. glabella $\mathrm{Na}$ análise foram incluídos todos os representantes do clado Micropiper (sensu Samain et al. 2009) (tabela 2) e para o grupo externo foram escolhidas quatro espécies que formam o clado irmão de Micropiper de acordo com Wanke et al. (2006) e Samain et al. (2009): Peperomia pernambucensis, $P$. lanceolatopeltata, P. magnoliifolia e P. galioides.

Tabela 1. Amostras de P. sp, P. glabella e suas variedades e P. alata, com localidades, voucher e marcadores que foram amplificados e utilizados nas análises moleculares e filogenéticas.

\begin{tabular}{|c|c|c|c|c|}
\hline Espécie & Localidade & Voucher & $\begin{array}{l}\text { trnK/ } \\
\text { matK }\end{array}$ & ITS \\
\hline P. $s p$. (Trindade) 1 & Ilha da Trindade & Moreira, (UB) & $\mathrm{X}$ & $\mathrm{X}$ \\
\hline P. sp. (Trindade) 2 & Ilha da Trindade & $\begin{array}{l}\text { Carvalho-Silva } 1787 \\
\text { (UB) }\end{array}$ & $\mathrm{X}$ & $\mathrm{X}$ \\
\hline P. sp. (Trindade) 3 & Ilha da Trindade & $\begin{array}{l}\text { Carvalho-Silva } 1785 \\
\text { (UB) }\end{array}$ & $\mathrm{X}$ & $\mathrm{X}$ \\
\hline P. sp. (Trindade) 4 & Ilha da Trindade & Faria, 259 (UB) & $\mathrm{X}$ & $\mathrm{X}$ \\
\hline P. sp. (Trindade) 5 & Ilha da Trindade & $\begin{array}{l}\text { Carvalho-Silva } 1782 \\
\text { (UB) }\end{array}$ & $\mathrm{X}$ & $\mathrm{X}$ \\
\hline P. sp. (Trindade) 6 & Ilha da Trindade & Moura, 422 (UB) & & $\bar{X}$ \\
\hline P. sp. (Trindade) 7 & Ilha da Trindade & Faria, $258(\mathrm{UB})$ & & $\mathrm{X}$ \\
\hline P. glabella $(\mathrm{PE})$ & Pernambuco, Jaqueira & Melo, 763 (RB) & $\mathrm{X}$ & $\mathrm{X}$ \\
\hline $\begin{array}{l}\text { P. glabella (SC) var. } \\
\text { glabella }\end{array}$ & $\begin{array}{lll}\text { Santa } & \text { Catarina, } & \text { Morro } \\
\text { Grande } & & \end{array}$ & Schmitt 876 (RB) & $\mathrm{X}$ & \\
\hline P. glabella $(\mathrm{RJ}) 1$ & Rio de Janeiro, Parati & $\begin{array}{l}\text { Carvalho-Silva } 339 \\
\text { (UB) }\end{array}$ & $\mathrm{X}$ & $\mathrm{X}$ \\
\hline P. glabella $(\mathrm{RJ}) 2$ & Rio de Janeiro, Teresópolis & $\begin{array}{l}\text { Carvalho-Silva } 2001 \\
\text { (UB) }\end{array}$ & $\mathrm{X}$ & $\mathrm{X}$ \\
\hline
\end{tabular}




\begin{tabular}{|c|c|c|c|c|}
\hline $\begin{array}{l}P . \text { glabella }(\mathrm{RJ}) 3 \text { var. } \\
\text { nigropunctata }\end{array}$ & $\begin{array}{l}\text { Rio de Janeiro, Cachoeira } \\
\text { do Macacu }\end{array}$ & $\begin{array}{ll}\text { Annete } & \text { Bonnet } \\
800108(\mathrm{RB}) & \end{array}$ & $\mathrm{X}$ & \\
\hline P. glabella $(\mathrm{RJ}) 4$ & Rio de Janeiro, Teresópolis & $\begin{array}{l}\text { Carvalho-Silva } 2003 \\
\text { (UB) }\end{array}$ & $\mathrm{X}$ & $\mathrm{X}$ \\
\hline P. glabella $(\mathrm{RJ}) 5$ & Rio de Janeiro, Teresópolis & $\begin{array}{l}\text { Carvalho-Silva } 1991 \\
\text { (UB) }\end{array}$ & $\mathrm{X}$ & \\
\hline P. glabella $(\mathrm{RJ}) 6$ & Rio de Janeiro & $\begin{array}{l}\text { Carvalho-Silva } 325 \\
\text { (UB) }\end{array}$ & $\mathrm{X}$ & $\mathrm{X}$ \\
\hline P. glabella $(\mathrm{RS})$ & $\begin{array}{l}\text { Rio Grande do Sul, Arroio } \\
\text { do Sal }\end{array}$ & $\begin{array}{ll}\text { Lippert } & \text { (PACA } \\
109167) & \end{array}$ & $\mathrm{X}$ & \\
\hline $\begin{array}{l}\text { P. glabella (CE)var. } \\
\text { glabella }\end{array}$ & Ceará, Guaramiranga & Barros $4350(\mathrm{RB})$ & $\mathrm{X}$ & $\mathrm{X}$ \\
\hline $\begin{array}{l}\text { P. glabella (ES)var. } \\
\text { glabella }\end{array}$ & Espírito Santo, Ibitirama & Couto $2301(\mathrm{RB})$ & $\mathrm{X}$ & $\bar{X}$ \\
\hline P. glabella $(\mathrm{MG}) 1$ & Minas Gerais & Barbosa, $82(\mathrm{RB})$ & $\mathrm{X}$ & $\mathrm{X}$ \\
\hline P. alata $(\mathrm{RJ})$ & Rio de Janeiro, Teresópolis & $\begin{array}{l}\text { Carvalho-Silva } 1974 \\
\text { (UB) }\end{array}$ & $\mathrm{X}$ & $\mathrm{X}$ \\
\hline
\end{tabular}

Tabela 2. Espécimes do Genbank utilizados nas análises filogenéticas e moleculares.

\begin{tabular}{|l|c|c|c|c|}
\hline \multicolumn{1}{|c|}{ Espécie } & $\begin{array}{c}\text { Acesso } \\
\text { Genbank - } \\
\text { MatK }\end{array}$ & & $\begin{array}{c}\text { Rcesso } \\
\text { Genbank - } \\
\text { ITS }\end{array}$ & Referência \\
\hline P. bicolor Sodiro & DQ212761 & Wanke et al. (2006) & FJ424465 & Samain et al. (2009) \\
\hline P. blanda (Jacq.) Kunth & DQ212763 & Wanke et al. (2006) & FJ424455 & Samain et al. (2009) \\
\hline P. clusiifolia (Jacq.) Hook. & DQ212753 & Wanke et al. (2006) & FJ424450 & Samain et al. (2009) \\
& & & & \\
\hline P. galioides Kunth & DQ212748 & Wanke et al. (2006) & DQ868694 & Garcia (não publicado) \\
& & & & \\
\hline
\end{tabular}




\begin{tabular}{|c|c|c|c|c|}
\hline P. glabella (Sw.) A. Dietr. & DQ212757 & Wanke et al. (2006) & FJ424454 & Samain et al. (2009) \\
\hline P. hylophila C. DC. & DQ212758 & Wanke et al. (2006) & FJ424456 & Samain et al. (2009) \\
\hline $\begin{array}{l}\text { P. inaequalifolia Ruiz and } \\
\text { Pav. }\end{array}$ & DQ212749 & Wanke et al. (2006) & FJ424453 & Samain et al. (2009) \\
\hline P. lanceolatapeltata C. DC. & DQ212750 & Wanke et al. (2006) & FJ424448 & Samain et al. (2009) \\
\hline P. lancifolia Hook. & DQ212755 & Wanke et al. (2006) & FJ424457 & Samain et al. (2009) \\
\hline $\begin{array}{l}\text { P. magnoliifolia (Jacq.) } \\
\text { A. Dietr. }\end{array}$ & DQ212752 & Wanke et al. (2006) & FJ424449 & Samain et al. (2009) \\
\hline $\begin{array}{l}\text { Peperomia obtusifolia (L.) A. } \\
\text { Dietr. }\end{array}$ & - & Wanke et al. (2006) & DQ868697 & Garcia (não publicado) \\
\hline P. pernambucensis Miq. & DQ212751 & Wanke et al. (2006) & FJ424451 & Samain et al. (2009) \\
\hline P. pitcairnensis C. DC. & DQ212762 & Wanke et al. (2006) & FJ424459 & Samain et al. (2009) \\
\hline P. polystachya C. DC. & FJ424468 & Samain et al. (2009) & FJ424458 & Samain et al. (2009) \\
\hline P. prostrata Williams & DQ212759 & Wanke et al. (2006) & FJ424462 & Samain et al. (2009) \\
\hline P. rotundifolia (L.) Kunth & DQ212754 & Wanke et al. (2006) & FJ424460 & Samain et al. (2009) \\
\hline P. tuisana C. DC. & DQ212756 & Wanke et al. (2006) & FJ424464 & Samain et al. (2009) \\
\hline
\end{tabular}


O DNA foi extraído segundo o protocolo de Doyle \& Doyle (1987) com modificações (Borsch et al. 2003). Para obter um DNA de melhor qualidade foram feitas extrações triplas com CTAB e lavagem dupla com SEVAG para minimizar os compostos secundários. Para amostras que tiveram dificuldade de obtenção de DNA da forma citada acima foi utilizado o protocolo de Doyle \& Doyle (1987) até a lavagem com SEVAG e em seguida o Kit Qiagen PCR Purification Kit \# 28106.

Foram amplificadas duas regiões do DNA: uma do cloroplasto (matK - em parte) e uma do núcleo (ITS), utilizando a técnica de Reação em Cadeia de Polimerase (PCR - Polymerase Chain Reaction) (Mullis \& Faloona 1987). Para amplificar as regiões foram utilizados os primers apresentados na tabela 3. O par de primers ARmatK-1200F e Pi-matK-1820R foi utilizado para amplificar a região do trnK/matK. Os primers ITS 4 e ITS 5 foram utilizados para amplificar a região do ITS em sua totalidade, mas quando não houve sucesso a região foi amplificada em duas partes com os pares: ITS 5 e ITS 2; ITS 3 e ITS 4. O protocolo padrão de PCR foi realizado para $50 \mu \mathrm{l}$ de solução, contendo $5 \mu \mathrm{l}$ de $\mathrm{Mg}$ buffer, $5 \mu \mathrm{l} \mathrm{MgCl}_{2}, 2 \mu \mathrm{l} \mathrm{BSA}, 4 \mu \mathrm{dNTP}$ mix, $0.5 \mu 1$ Taq polimerase e 2,5 $\mu 1$ de cada primer, $2 \mu$ de DNA e 26,5 $\mu 1$ de água Milli-Q.

Tabela 3. Primers utilizados para a amplificação do trnK/matK e ITS.

\begin{tabular}{|c|c|c|c|c|}
\hline Primer & Direção & Região & Sequências 5'-3' & Referência \\
\hline AR-matK-1200F & Foward & trnK-matK & TTC CAA AGT CAA AAG AGC G & Wanke et al. (2006) \\
\hline Pi-matK-1820R & Reverse & trnK-matK & ACA CTA ATT GGA AGG AGA ATG G & Wanke et al. (2006) \\
\hline ITS 5 & Foward & ITS & GGA AGT AAA AGT CGT AAC AAG G & $\begin{array}{c}\text { Baldwin } \text { et al. } \\
(1995)\end{array}$ \\
\hline ITS 2 & Reverse & ITS & GCT GCG TTC TTC ATC GAT GC & $\begin{array}{c}\text { Baldwin } \text { et al. } \\
(1995)\end{array}$ \\
\hline ITS 3 & Foward & ITS & GCA TCG ATG AAG AAC GCA GC & $\begin{array}{c}\text { Baldwin } \text { et al. } \\
(1995) \\
\text { ITS 4 }\end{array}$ \\
& Reverse & ITS & TCC TCC GCT TAT TGA TAT GC & $\begin{array}{c}\text { Baldwin } \text { et al. } \\
(1995)\end{array}$ \\
\hline
\end{tabular}

A amplificação por PCR ocorreu em 35 ciclos. Cada ciclo formado por 30 segundos a $95^{\circ} \mathrm{C}, 45$ segundos de 48 a $56^{\circ} \mathrm{C}$ e 1 minuto a $72^{\circ} \mathrm{C}$. O ciclo inicial de $95^{\circ} \mathrm{C}$ tem duração de 1 minuto e a extensão final de $72^{\circ} \mathrm{C}$ por 5 minutos. A purificação e o sequenciamento foram feitos pela Macrogen Inc. (Coréia). A extração e amplificação 
foram feitas no Laboratório de Biologia Molecular de Plantas do Departamento de Botânica da Universidade de Brasília.

Neste estudo, inicialmente, o $\operatorname{trnK} / m a t K$ de amostras de $P$. sp.e as de $P$. glabella foi sequenciado por completo, mas as diferenças estavam aproximadamente entre os pares de base 30 e 210. Por isso, foi amplificada apenas esta região e comparada com o maior número de amostras de $P$. glabella que foi possível realizar a extração do DNA e a amplificação das regiões desejadas.

As sequências foram editadas e montadas no Codoncode Aligner (v. 4.0.4 Codon Code Corporation), o alinhamento foi feito utilizando o CLUSTALX 2.1 (Higgins \& Sharp 1988) e por comparação visual com ajustes no PhyDE (v. 0.9971). As análises de Máxima Parcimônia foram realizadas no PAUP v.4.0b10 para Macintosh (Swofford 2002), as de Máxima Verossimilhança no GARLI v.0951 para Macintosh (Zwickl 2006) e as análises Bayesianas no Mr Bayes v. 3.2.1 (Ronquist \& Huelsenbeck, 2003).

O modelo de substituição nucleotídica utilizado foi o GTR (General Time Reversible). Quatro cadeias de Markov Chain Monte Carlo foram executadas para 5.000.000 gerações, em duas corridas pararelas. O primeiro $25 \%$ das árvores foram descartados como "burn-in". Inserções/deleções foram utilizadas nas análises e codificadas quando necessário.

O suporte da árvore filogenética foi avaliado através do bootstrap não paramétrico (Felsenstein 1985) com 1.000 repetições para Máxima Parcimônia, 100 repetições para Máxima Verossimilhança e probabilidades posteriores para Bayesiana.

A divergência média interespecífica foi gerada a partir do software PAUP v.4.0b10 para Macintosh (Swofford 2002).

\subsection{Morfologia}

Foram analisadas 200 exsicatas, oriundas de empréstimos, depositadas nos herbários: BHCB, CEN, CEPEC, FLOR, FURB, HRCB, HUCS, HUEFS, IAC, IAN, IPA, MBM, PACA, R, RB, SP, SPSF, UB, VIC e VIES, além dos materiais tipos 
depositados nos herbários G e NY (siglas segundo Thiers 2014). Foram analisados exemplares de Peperomia glabella e as variedades da espécie (Anexo 1).

Três expedições de coleta na Ilha da Trindade e duas coletas no continente foram realizadas durante o período de dois anos. O material coletado está depositado no herbário UB.

A morfologia dos órgãos vegetativos e reprodutivos foi analisada com utilização do microscópio estereoscópico LEICA EZ4D. Medidas de comprimento e largura da folha, tamanho do pecíolo, e tamanho do $4^{\circ}$ e $10^{\circ}$ nó foram feitas com utilização de paquímetro digital. E a Análise de Componentes Principais foi feita utilizando o software PAST (Hammer et al. 2001).

\section{Resultados}

\subsection{Análises Moleculares}

No alinhamento do trnk/matK existem duas mutações nos espécimes de $P$. sp.com relação as $P$. glabella. A primeira é uma transversão localizada na posição 34, onde todas as outras Peperomia possuem um C e as da Ilha um A (figura 2). A segunda é uma inserção (repetição) de 19 pares de base no DNA das $P$. sp. que as outras Peperomia não possuem, localizada na posição 182 (figura 3). Analisando a mesma região do trank/matK em espécies próximas filogeneticamente, como exemplo de $P$. magnoliifolia G. Mathieu e P. clusiifolia (Jacq.) Hook., (Wanke et al. 2006), são encontradas apenas duas mutações que as diferenciam, sendo uma transversão e uma transição.

A mesma análise do alinhamento com o espaçador ITS não mostra mutações que ocorram somente em $P$. glabella ou em $P$. sp. O alinhamento de trnK/matK e ITS não mostrou nenhuma diferença entre as variedades de Peperomia glabella var. glabella e P. glabella var. nigropunctata amostradas. A Peperomia glabella var. nervulosa não foi amostrada porque não foi encontrado material viável para extração de DNA.

A análise de divergência média interespecífica com a região do gene trnK/matK apresentou média de 0,004 entre as $P$. glabella e as $P$. sp. Entre $P$. magnoliifolia e $P$. clusiifolia o valor para esta mesma região é 0,003 . Na região ITS a média entre $P$. 
glabella e as Peperomia de Trindade foi 0,01 e o valor entre $P$. magnoliifolia e $P$. clusiifolia é 0,004 .

Peperomia fernandopoiana C.DC., espécie africana, mais próxima morfologicamente a $P$. glabella e $P$. sp.foi incluída no clado Micropiper segundo a classificação de Samain et al. (2009), assim como P.glabella e a P. sp., mas mostrou que é filogeneticamente mais próxima de Peperomia tuisana C. DC.

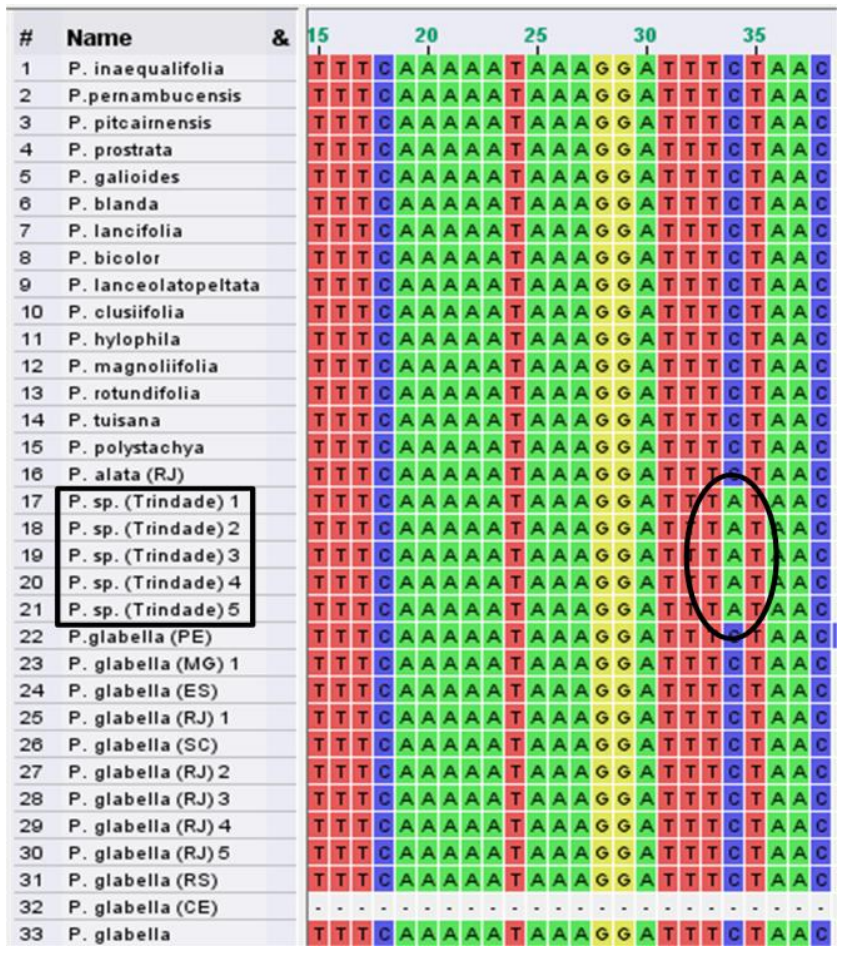

Figura 2. Matriz alinhada trnK/matK. Em destaque a transversão de $\mathrm{C}$ para A na posição 34 que ocorre apenas em $P$. sp.Entre parênteses estão as localidades dos espécimes, os que não possuem são sequências obtidas do GenBank. 


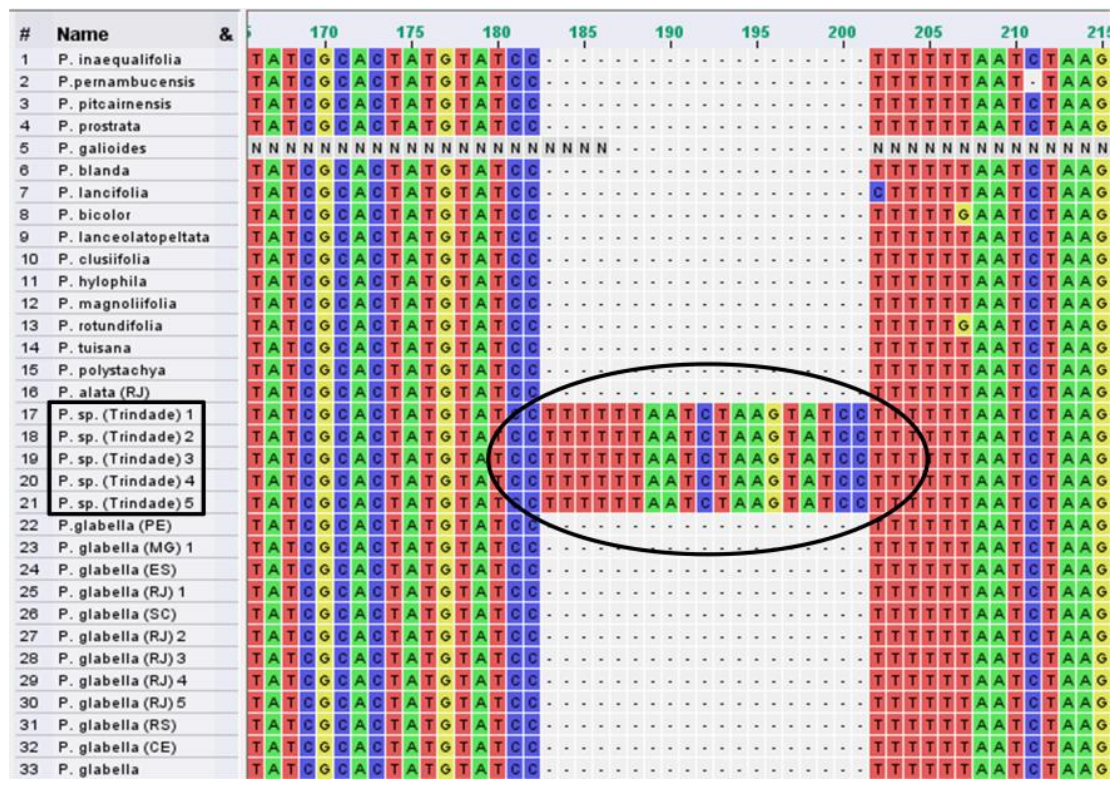

Figura 3. Matriz alinhada trnK/matK. Em destaque a inserção de 19 pares de bases que ocorre apenas em $P$. sp. Entre parênteses estão as localidades dos espécimes, os que não possuem são sequências obtidas do GenBank.

Os cladogramas gerados, tanto com trnK/matk quanto com ITS, mostram que a $P$.sp. está no mesmo clado que Peperomia glabella, clado Micropiper segundo Samain et al. (2009). As análises do trnK/matK apresentam as $P$. sp. formando um clado (Clado II) dentro do clado de $P$. glabella com suporte baixo (Clado I) (figura 4). 


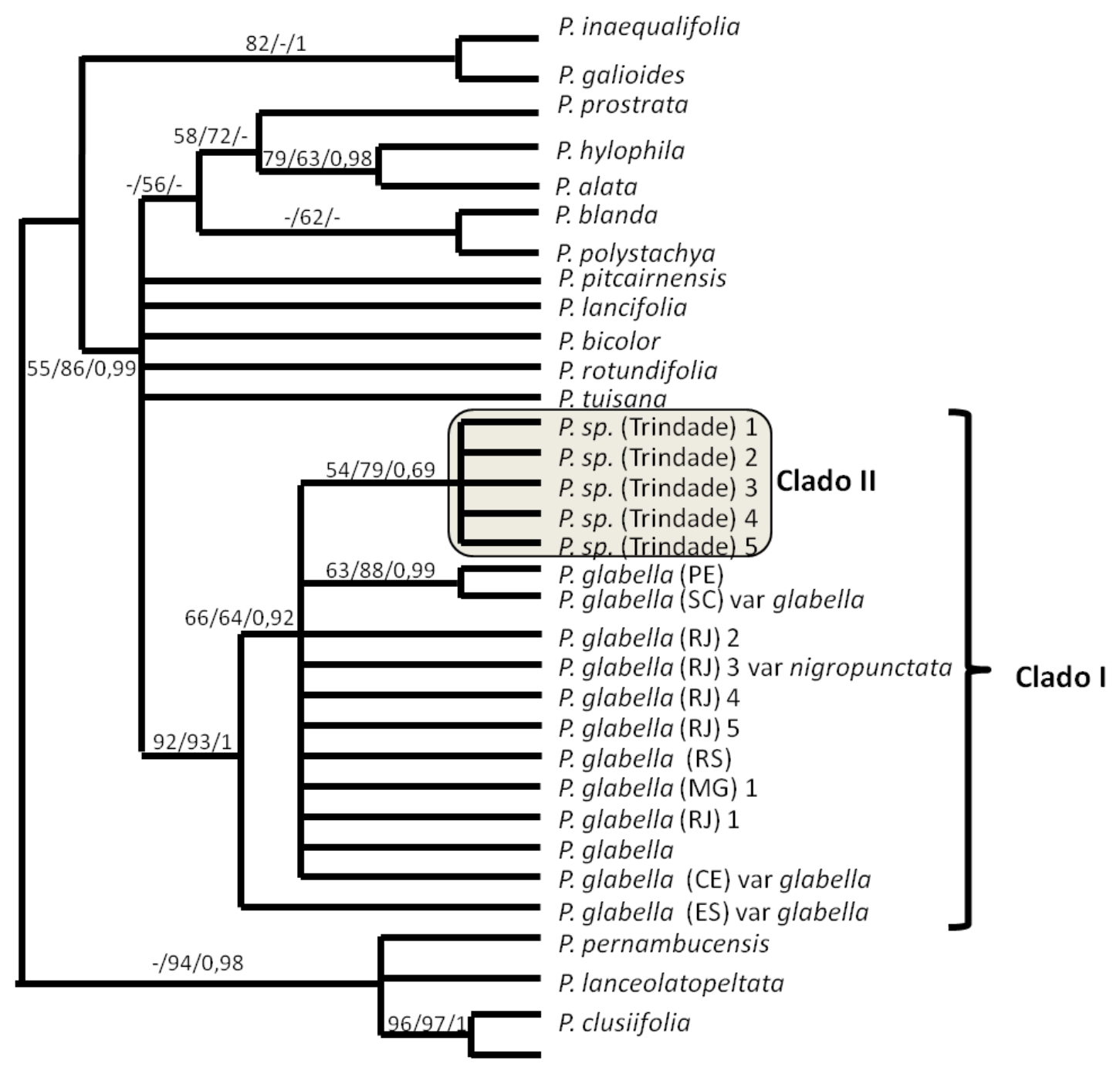

Figura 4. Árvore consenso de Máxima Verossimilhança (MV) do trnK/matK, mostrando as $P$. glabella e as $P$. sp. Os números próximos aos ramos são os valores de bootstrap para Máxima Parcimônia e Máxima Verossimilhança, e probabilidades posteriores para Bayesiana, respectivamente.

As análises do espaçador ITS mostraram a formação do clado I com bom suporte (77/92/1) nos três tipos de análises, composto pelas $P$. glabella e pelas $P$. sp. (figura 5). 


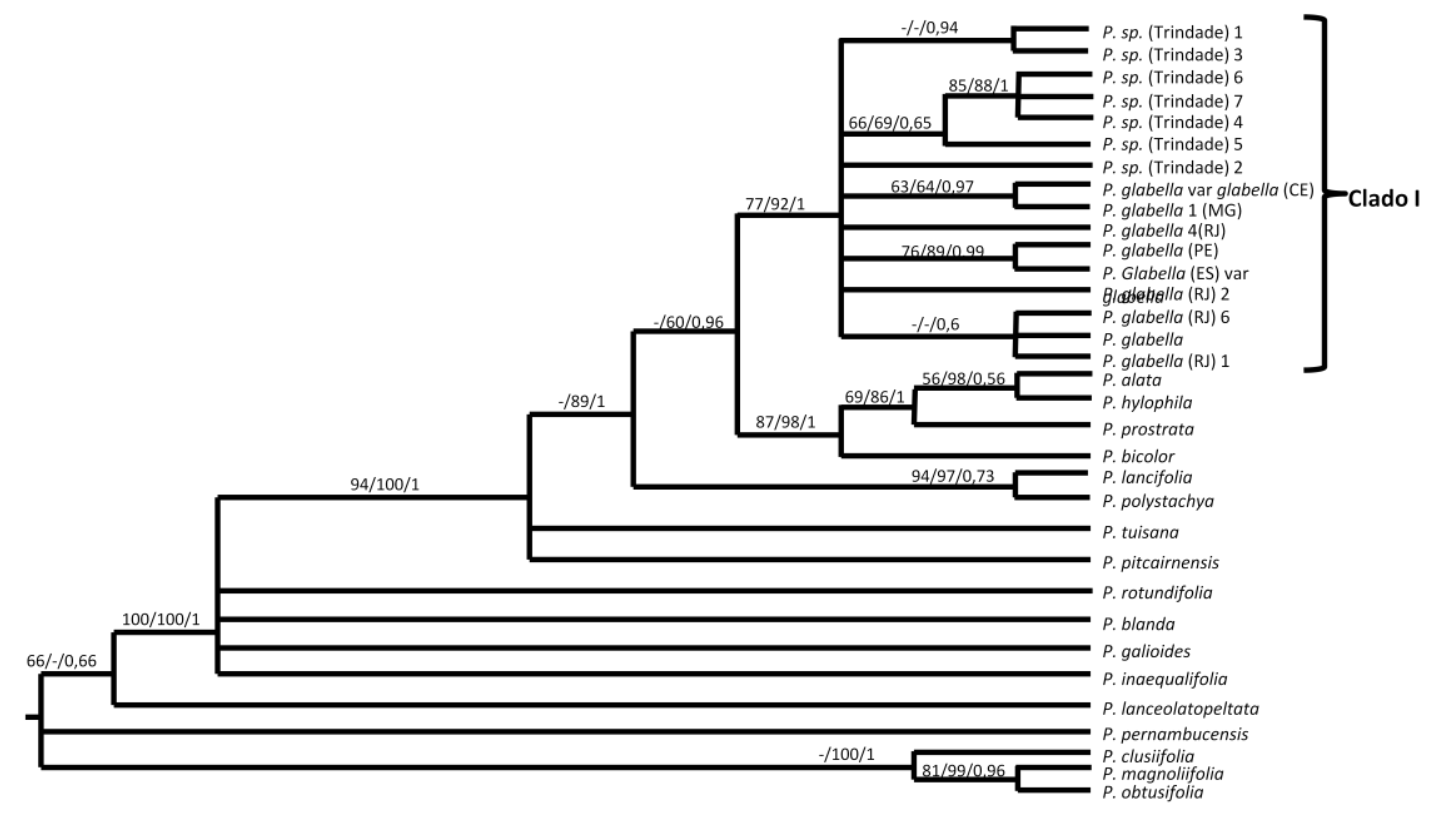

Figura 5. Árvore consenso de Análise Bayesiana (B) do espaçador ITS, mostrando as $P$. glabella do continente e as Peperomia de Trindade. Os números próximos aos ramos são os valores de bootstrap para Máxima Parcimônia e Máxima Verossimilhança, e probabilidades posteriores para Bayesiana, respectivamente. 


\subsection{Morfologia}

Na Ilha da Trindade foi encontrada uma grande população de $P$. sp. no Pico do Desejado, na trilha para a Floresta de Samambaia com alguns indivíduos espalhados dentro da Floresta de Samambaia, altitude cerca de 500 a 620 m (figura 6).

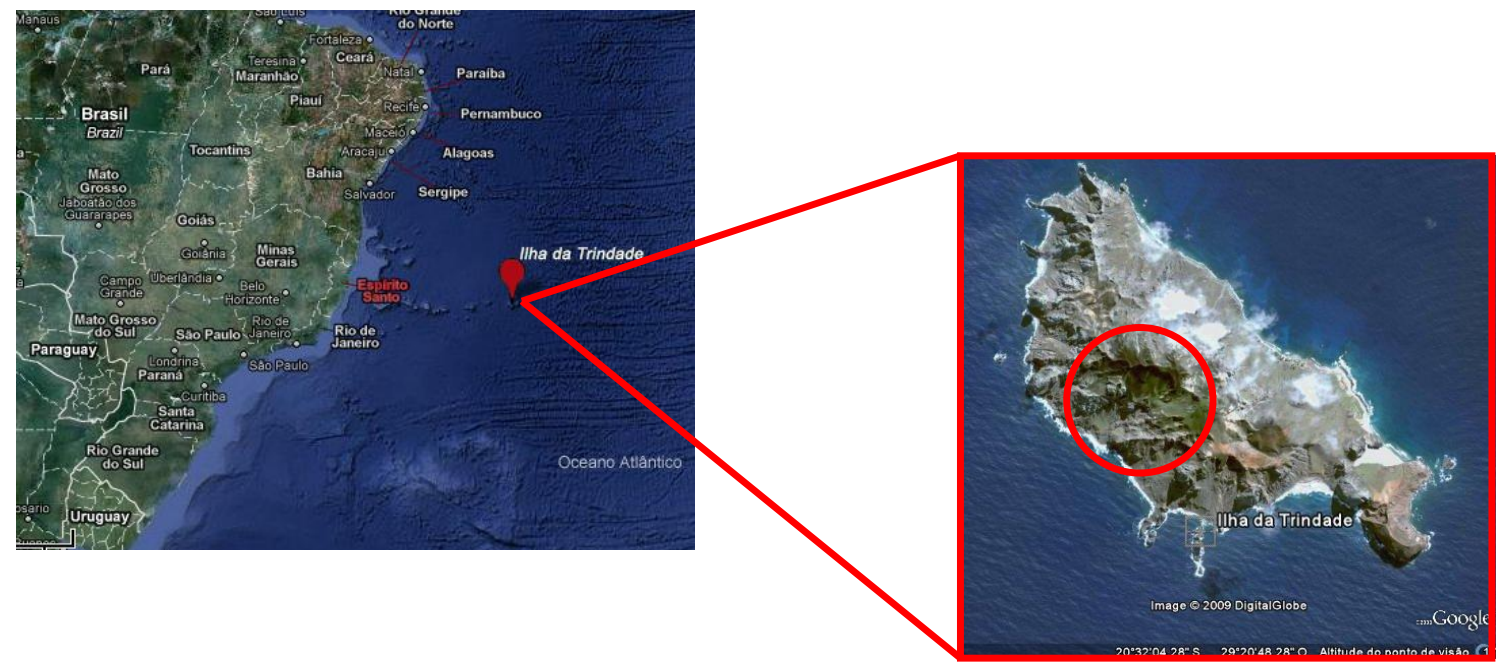

Figura 6. Localização da Ilha da Trindade, em destaque a Floresta de Samambaias Gigantes.

As plantas desta população são frequentemente ervas terrestres, com filotaxia alterna espiralada (figura 7 B-D), com poucos indivíduos com ramos subindo e escorando na base dos troncos das samambaias gigantes. São plantas que crescem no solo e ocorrem em local sombreados, principalmente embaixo das samambaias gigantes, raramente são encontrados espécimes em locais menos sombreados. São encontradas nos locais de alta altitude da Ilha, onde existe vegetação arbórea.

Os espécimes de $P$. glabella analisados são ervas epífitas com ramos pêndulos (figura 7 A e C) e apresentam uma grande variedade no formato da folha variando de elíptico-oval, rômbico, longo-elíptico, elíptica a arredondada. A largura varia de 0,6 a $2,8 \mathrm{~cm}$ e o comprimento de 1,4 a $6,9 \mathrm{~cm}$. As folhas são glabras e com glândulas em ambas as faces, quando secas. $\mathrm{O}$ ápice varia de agudo a acuminado, possui tricomas, a base varia de aguda a atenuada e a margem é glabra. O pecíolo é levemente ciliado e canaliculado. As anteras não possuem glândulas negras (figura $8 \mathrm{~B}$ ). Na tabela 4 é feita a comparação morfológica da $P$. sp., $P$. glabella e suas variedades encontradas no continente. 

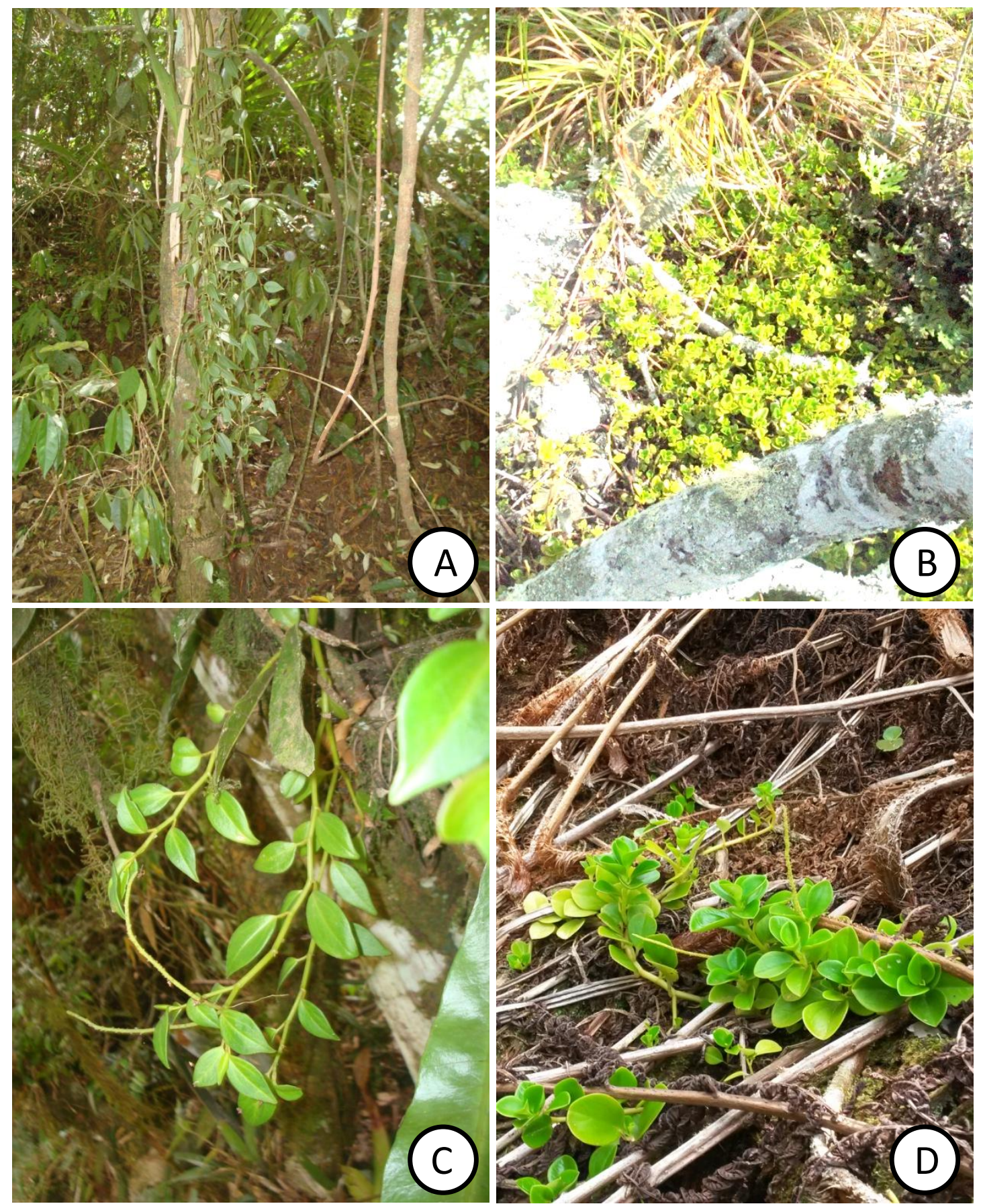

Figura 7. Hábito, filotaxia e tamanho dos entrenós de $P$. glabella e $P$. sp. A - Hábito de Peperomia glabella; B - Hábito de P. sp. ; C - entrenós de Peperomia glabella; D - entrenós de $P$. sp. 


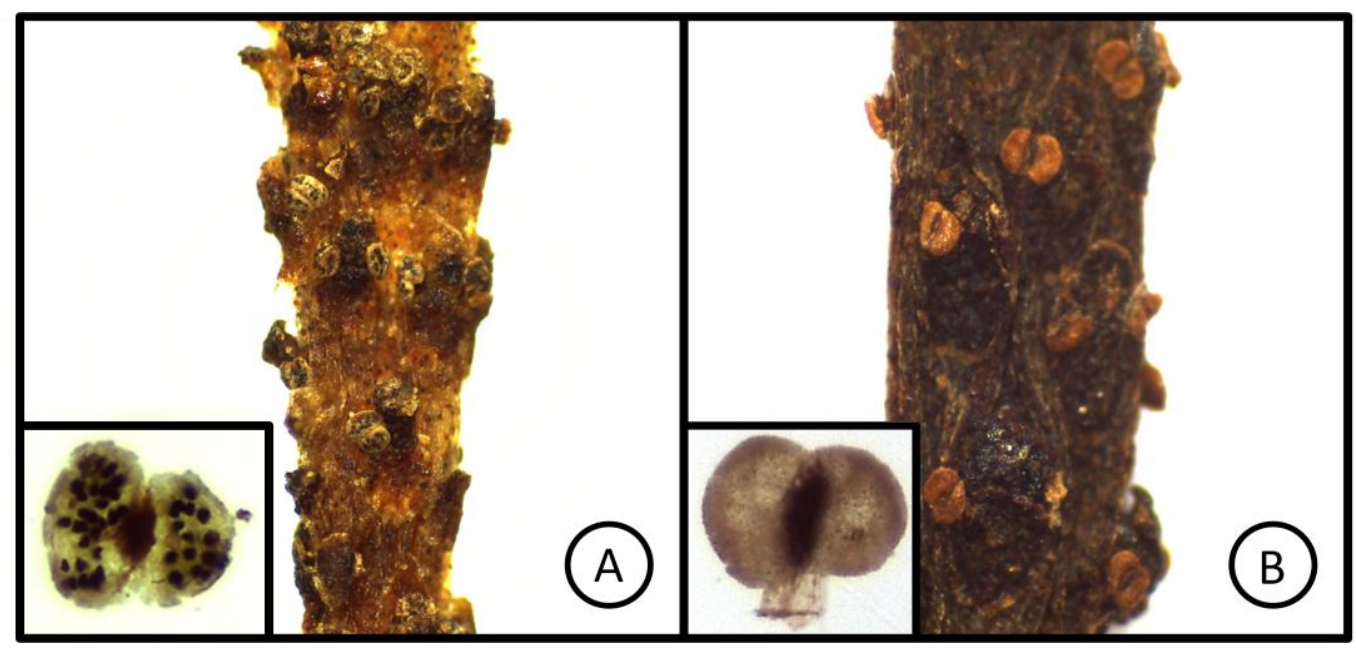

Figura 8. Anteras de $P$. sp. e $P$. glabella. A. $P$. sp. com a presença de glândulas negras nas anteras. B. P. glabella sem glândulas negras nas anteras. (Vouchers: A- Dantas 110 - UB; BRaimundo S. P. 1030 - RB).

Tabela 4. Comparação de características morfológicas de Peperomia sp., P. glabella e suas variedades, segundo Yuncker (1974) e Alves e Guimarães 1998, com modificações.

\begin{tabular}{|c|c|c|c|c|c|c|}
\hline & Peperomia sp. & P. glabella & $\begin{array}{l}\text { P. glabella } \\
\text { var. glabella }\end{array}$ & $\begin{array}{l}\text { P. glabella } \\
\text { var. nervulosa }\end{array}$ & $\begin{array}{l}\text { P. glabella var. } \\
\text { nigropunctata }\end{array}$ & $\begin{array}{l}P . \\
\text { beckeri }\end{array}$ \\
\hline Hábito & Terrestre & Epífita & Epífita & Epífita & Epífita & $\begin{array}{l}\text { Não } \\
\text { informado }\end{array}$ \\
\hline $\begin{array}{l}\text { Formato } \\
\text { da folha }\end{array}$ & $\begin{array}{l}\text { Ovada } \\
\text { obovada }\end{array}$ & $\begin{array}{l}\text { elíptica-oval, } \\
\text { rômbica, } \\
\text { longa-elíptica, } \\
\text { elíptica a } \\
\text { arredondada }\end{array}$ & $\begin{array}{l}\text { Ovada ou } \\
\text { elíptica- } \\
\text { lanceolada }\end{array}$ & Lanceolada & $\begin{array}{l}\text { Elíptica- } \\
\text { lanceolada, } \\
\text { subovada, } \\
\text { elíptica- } \\
\text { obovada ou } \\
\text { subrômbica }\end{array}$ & Obovada \\
\hline $\begin{array}{l}\text { Tamanho } \\
\text { da folha }\end{array}$ & $\begin{array}{l}1.4-4 \mathrm{~cm} \mathrm{de} \\
\text { comp, } \\
1.1-2.7 \mathrm{~cm} \mathrm{de} \\
\text { larg }\end{array}$ & $\begin{array}{l}1,4 \text { a } 6,5 \mathrm{~cm} \text { de } \\
\text { comp. } \\
0,7 \text { a } 2,6 \mathrm{~cm} \mathrm{de} \\
\text { larg }\end{array}$ & $\begin{array}{l}1,4-5,6 \mathrm{~cm} \\
\text { de comp } \\
0,6-2,8 \mathrm{~cm} \\
\text { de larg }\end{array}$ & $\begin{array}{l}2,4-6,9 \mathrm{~cm} \mathrm{de} \\
\text { comp } \\
0,9-2,4 \mathrm{~cm} \mathrm{de} \\
\text { larg }\end{array}$ & $\begin{array}{l}2,9-4,2 \mathrm{~cm} \mathrm{de} \\
\text { comp } \\
1,5-2,4 \mathrm{~cm} \mathrm{de} \\
\text { larg }\end{array}$ & $\begin{array}{l}3,5-4 \\
\mathrm{~cm} \quad \mathrm{de} \\
\text { comp, } 1,7 \\
-2 \mathrm{~cm} \mathrm{de} \\
\text { larg. }\end{array}$ \\
\hline
\end{tabular}

As $P$. sp. apresentam as folhas adultas ovadas ou obovadas, com largura entre 1,1 e 2,7 cm e comprimento entre 1,4 e $4 \mathrm{~cm}$. As folhas são glabras e com glândulas negras em ambas as faces, quando secas. O ápice é obtuso e possui tricomas, a base varia de obtusa a aguda e a margem é glabra. O pecíolo é levemente ciliado e canaliculado. As anteras também apresentam glândulas negras (figura 8A). A morfometria realizada com espécimes de $P$. glabella, suas variedades e as $P$. sp. mostrou que não é possível separar $P$. glabella, suas variedades e $P$. sp. pelo tamanho da folha, do pecíolo e dos entrenós (figura 9). 


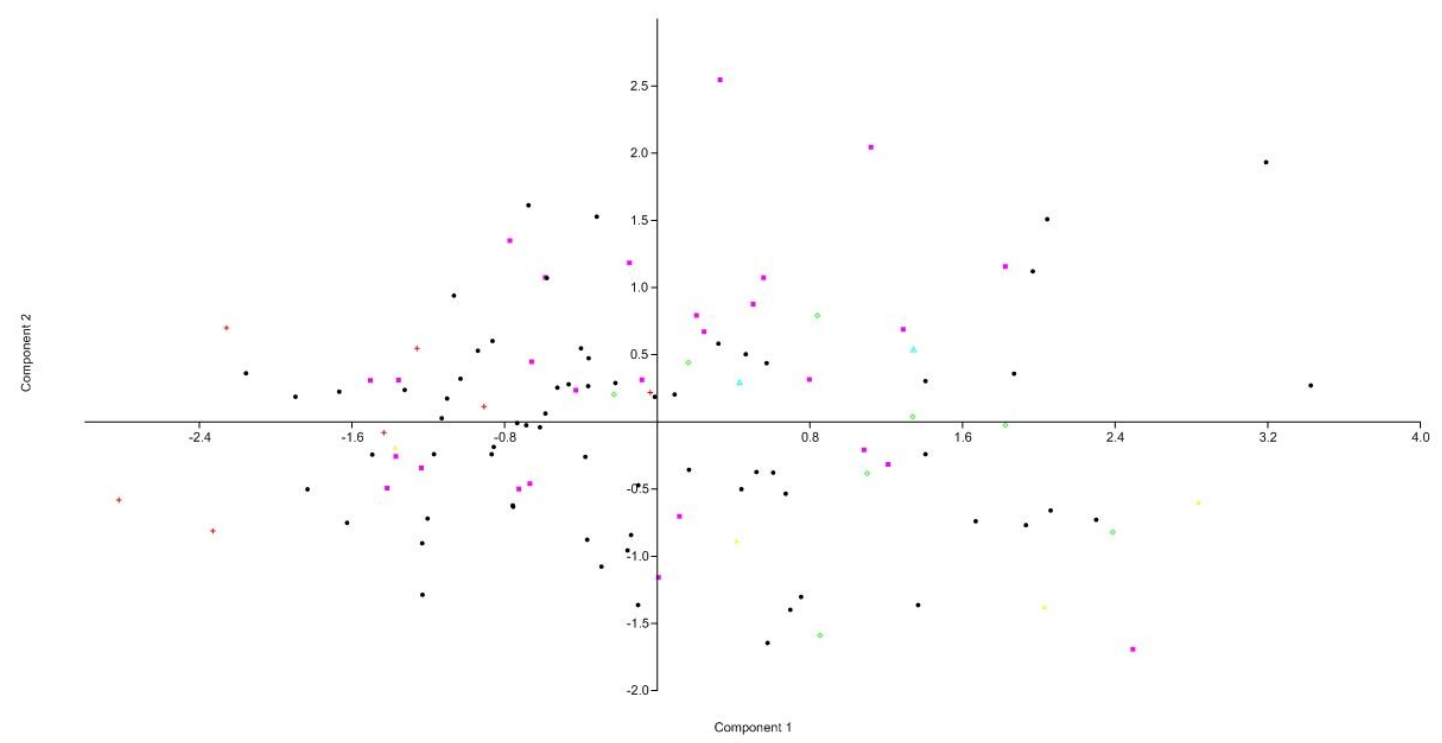

Figura 9. Análise de componentes principais. P. glabella em preto; P. glabella var. glabella em rosa; $P$. glabella var. nervulosa em verde; $P$. glabella var. nigropunctata em amarelo; P. glabella var. nudipetiolata em azul claro; P. glabella da Ilha da Trindade em vermelho.

\section{Discussão}

As três variedades de Peperomia glabella aceitas por Yuncker (1974) para o Brasil ( $P$. glabella var. glabella, P. glabella var. nigropunctata e P. glabella var. nervulosa) têm sido separadas pelo tamanho e formato da folha e pilosidade do pecíolo. Nas Peperomia glabella que foram estudadas foi observado uma grande variação no formato e tamanho das folhas, inclusive na mesma planta. Muitas vezes não foi possível identificar a variedade pelo fato de a planta apresentar no mesmo espécime formatos e tamanhos de folhas que ora pertencem a duas ou três variedades. Acredita-se que o tamanho e formato das folhas pode não ser uma característica importante para separar as variedades, pois já nas descrições os tamanhos das folhas são sobrepostos entre as variedades $P$. glabella var. nigropunctata e $P$. glabella var. nervulosa impossibilitando a sua identificação. Com a utilização da morfometria foi possível perceber que o tamanho da folha não é informativa para separar as variedades.

Os pecíolos das folhas das plantas observadas são levemente ciliados e em alguns casos glabros, quando observados no microscópio estereoscópico, mas não foi 
observada nenhuma relação com a identificação da variedade. Os tricomas são encontrados em grande quantidade nos pecíolos das folhas jovens. Com essas análises foi possível perceber que as características utilizadas para separar estas variedades não são suficientes para diferenciá-las. São características que se sobrepõem e não possibilita a identificação das variedades. Os dados moleculares, assim como os dados morfológicos sugerem que todos os espécimes analisados para o Brasil pertencem a mesma espécie, sugerindo uma sinonimizacão das variedades nigropunctata e nervulosa a $P$. glabella var. glabella.

Embora os espécimes encontrados na Ilha da Trindade sejam identificados como P. glabella, estudos preliminares sugerem que a $P$. glabella encontrada na Ilha da Trindade é morfologicamente distinta de P. glabella encontrada no continente. A biodiversidade de ilhas, geralmente, é bastante particular (Serafini 2010) e o que chama a atenção em Trindade não é a diversidade e sim o número de espécies endêmicas, cerca de $10 \%$ das plantas são endêmicas (Gusmão 2005), devido ao isolamento geográfico. Sendo possível que a Peperomia que é encontrada atualmente na Ilha da Trindade seja uma espécie endêmica.

Segundo Alves \& Guimarães (1998), ocorrem na Ilha da Trindade Peperomia beckeri, P. glabella var. glabella e P. glabella var. nigropunctata. P. beckeri é considerada endêmica e é conhecida apenas pelo material tipo. Esta espécie possui folha em verticilo de 3 à 4, obovada com 3,5-4 cm de comprimento, 1,7-2 cm de largura, glândulas em ambas as faces, espiga terminal, flores densamente aglomeradas e anteras com glândulas vermelhas. O tamanho e formato da folha e a presença de folhas congestas no ápice são características comuns também à Peperomia sp., e as duas espécies poderiam ser confundidas, mas Peperomia sp. apresenta as folhas alternas espiraladas e glândulas negras nas anteras.

O fato de só existir apenas um exemplar de P. beckeri e este ser uma material escasso, com poucas folhas e ainda colado na exsicata, uma análise mais aprofundada para saber se estas duas não são a mesma espécie é dificultada. E como o material é antigo, coletado em 1965 e o holótipo, também não é possível a retirada para estudo molecular. No entanto, segundo a descrição dos autores da espécie, ela seria diferente da $P$. sp., pois apresenta filotaxia verticilada, flores desamente aglomeradas e presença de glândulas vermelhas De acordo com Alves \& Guimarães (1998), a população de $P$. 
beckeri era restrita a um único local e em expedições realizadas ao mesmo local esta planta não foi encontrada (Alves \& Guimarães 1998; da Silva et al. 2013), portanto a espécie permanece conhecida apenas pelo material tipo (Alves \& Guimarães 1998) e é considerada extinta (da Silva 2013).

Todos os espécimes analisados de Peperomia glabella possuem o hábito epifítico com os ramos pêndulos, enquanto $P$. sp. ocorrem frequentemente no solo e em raros espécimes foram observados alguns ramos ascendentes subindo e escorando na base das samambaias gigantes. Uma explicação para essa diferença seria a impossibilidade do epifitismo em Trindade, já que o local onde as Peperômias ocorrem não há arbustos ou árvores além da samambaia gigante.

As folhas de $P$. sp. são frequentemente congestas no ápice dos ramos e espiraladas, sendo exceção poucos ramos, aqueles estão em locais bem sombreados e tendem a subir nas bases dos troncos da samamabaias gigantes. Já as folhas de Peperomia glabella são sempre dispostas mais laxamente nos ramos, não sendo observado nenhum exemplar com folhas congestas nos ápice dos ramos como as Peperomia da Ilha da Trindade. Considerando o formato e tamanho das folhas, geralmente $P$. glabella apresenta formato elíptico e uma variação maior de tamanho e sobreposição entre as variedades, enquanto a $P$. sp. normalmente é ovada e menor variação de tamanho. Ambas as plantas possuem dimorfismo foliar, muitas vezes possuindo as folhas na base dos ramos menores e ovadas. No entanto, a característica que diferencia claramente $P$. glabella de $P$. sp. é a presença de glândulas nas anteras nesta última, que $P$. glabella, e nenhuma de suas variedades, não possui. Além do hábito terrestre e as folhas alternas espiraladas.

Quanto aos caracteres moleculares o gene matK é conhecido pela alta variedade entre os genes de cloroplasto (Hilu \& Liang 1997; Borsch et al. 2005). Mutações como a da figura 2 são chamadas de mutações pontuais, que é a mudança de um único par de base (Lodish et al. 1995). Neste caso houve uma transversão, uma pirimidina (C) foi substituída por uma purina (A), isso pode ser causado por radiação ultravioleta e/ou por erro no pareamento (Griffiths et al. 1999). A inserção mostrada na figura 3 pode ser gerada por um evento conhecido como escorregão da polimerase (Polymerase Slippage), onde ocorre um deslizamento da fita e o aumento do comprimento após a próxima rodada de replicação (McMurray 2010). É mais provável que tenha ocorrido 
um único evento inserindo os 19 pares de bases do que vários eventos distintos. As células vivas têm um evoluído sistema de reparo do DNA. A taxa de mutação instantânea é baixa, indicando a eficiência destes sistemas de reparos. No entanto, falhas destes sistemas podem levar a uma alta taxa de mutação (Griffiths et al. 1999). E por não ter havido o reparo no DNA estas mutações foram passadas para as próximas gerações, se estabelecendo na Ilha. Existem mutações que são prejudiciais para o fitness da espécie, estas geralmente diminuem a sobrevivência ou a fertilidade (Eyre-Walker \& Keightley 2007). No entanto, isso não ocorreu com a $P$. sp., pois segundo Alves (1998) a única espécie que prospera, na floresta nebular, entre as plantas arbustivas e subarbustivas, é a Peperomia.

Os cladogramas gerados com o trnK/matK e o ITS mostram, com um suporte bom, que a $P$. sp. está no mesmo clado que a $P$. glabella. Ou seja, que a $P$. sp. realmente é mais próxima filogenéticamente de P. glabella. No entanto, os cladogramas gerados apenas com o trnK/matk mostram a formação de um clado apenas com as plantas de Trindade, que apesar de apresentar um baixo suporte, pode ser interpretado como uma espécie diferente de $P$. glabella pelas mutações apresentadas e pela divergência média interespecífica em comparação com outras espécies.

Comparando as diferenças genéticas entre P. magnoliifolia e P. clusiifolia, filogeneticamente espécies irmãs, porém distintas, foram encontradas duas mutações, uma transição e uma transversão. A mesma comparação entre a $P$. sp. e $P$. glabella também mostra duas mutações, uma transversão e uma inserção. A análise da divergência média interespecífica mostrou, tanto no $\operatorname{trn} K / \mathrm{matK}$ quanto no ITS, que a diferença entre a Peperomia de Trindade e P. glabella é maior do que P. magnoliifolia e $P$. clusiifolia, que são consideradas duas espécies diferentes. Sendo assim, mesmo que nas análises filogenéticas o bootstrap e a probabilidade posterior tenham sido baixos, é possível considerar a $P$. sp. uma espécie diferente de $P$. glabella, considerando também as diferenças morfológicas e de hábito.

Valdebenito et al (1990) estudaram a morfologia, geografia e observações em campo de Peperomia berteroana Miq. da Ilha de Juan Fernandez e compararam com Peperomia tristanensis Christoph. da Ilha de Tristão da Cunha. Apesar de haver diferenças entre elas, os dados indicam que devem ser tratadas como subespécies $(P$. berteroana subsp. berteroana e $P$. berteroana subsp. tristanensis) e não como espécies 
distintas, pois mesmo as poucas características que seriam diagnósticas de cada espécie muitas vezes se sobrepõem. Já no caso de $P$. glabella e a $P$. sp. também podem ocorrer algumas sobreposições, como o tamanho da folha e formato, mas existem características que são únicas da $P$. sp., como o hábito terrestre, a presença de glândulas negras nas anteras (que nem mesmo a $P$. glabella var. nigropunctata apresenta) e as folhas alternas espiraladas, além das diferenças genéticas observadas.

Valdebenito et al. (1992) estudaram a evolução das quatro espécies de Peperomia que ocorrem em Juan Fernandez, no Chile (P. berteroana, P. margaritifera, $P$. skottsbergii e P. fernandeziana), resultados baseados na morfologia, e concluíram que $P$. berteroana, $P$. margaritifera, $P$. skottsbergii são endêmicas e que o ancestral delas foi introduzido na ilha em época diferente de $P$. fernandeziana, que ocorre também no continente. E que provavelmente a dispersão para esta ilha oceânica tenha sido por através de aves, pois os frutos deste gênero possuem pericarpo coberto por papilas viscosas, tornando-se adesivas, e podem ser dispersas pelas penas de aves migratórias. Levando em consideração que esta ilha provalvemente nunca foi ligada a nenhum continente (Stuessy et al. 1984). O fato de $P$. sp. ser mais próxima filogeneticamente de $P$. glabella nos permite inferir que $P$. sp. originou-se a partir de Peperomia glabella, num evento conhecido como anagênese, onde uma população original chega a uma ilha podendo se ampliar e espalhar, acumulando modificações morfológicas e genéticas, sendo considerada taxonomicamente e biologicamente uma nova espécie (Stuessy et al. 2006, 2014). Com o passar do tempo e devido ao isolamento geográfico essas mutações genéticas e morfológicas foram se acumulando de forma que a população fundadora de Peperomia glabella oriunda do continente não é mais P. glabella e sim Peperomia sp. Assim como em Juan Fernandez a dispersão da Peperomia para a Ilha da Trindade provalvelmente tenha ocorrido através de aves, devido à longa distância do continente e à característica do fruto deste gênero.

\section{Referências Bibliográficas}

Almeida, F.F.M. 2000. A Ilha da Trindade. In: Schobbenhaus, C., Campos,D.A., Queiroz, E.T., Winge, M., Berbert-Born, M. (Edit.). Sítios Geológicos e Paleontológicos do Brasil. Atualmente em http://sigep.cprm.gov.br/sitio092/sitio092.htm 
Alves, R.J.V. \& Guimarães, E.F. 1998. Piperaceae da Ilha da Trindade. Bradea 8(17): 97-100.

Alves, R.J.V. 1998. Ilha da Trindade e Arquipélago Martin Vaz - Um Ensaio Geobotânico. Serviço de Documentação. Marinha do Brasil Rio de Janeiro. Diretoria de Hidrografia e Navegação.

Baldwin, B. G., Sanderson, M. J., Porter J. M. Wojciechowski M. F., Campbell, C. S., Donoghue M. J. 1995. The ITS region of nuclear ribosomal DNA: a valuable source of evidence of angiosperm phylogeny. Annals of the Missouri Botanical Garden 82: 247-277.

Borsch, T., Hilu, K.W., Quandt, D., Wilde, V., Neinhuis, C., Barthlott, W. 2003. Noncoding plastid trnT-trnF sequences reveal a well resolved phylogeny of basal angiosperms. Journal of evolutionary biology 16(4): 558-576.

Borsch, T., Lohne, C., Muller, K., Hilu, K.W., Wanke, S., Worberg, A., Barthlott, W., Neinhuis, C., Quandt, D. 2005. Towards understanding basal angiosperm diversification: recent insights using rapidly evolving genome regions. Nova Acta Leopold. 92: 85-110.

Bozzola, J. J. \& Russel, L. D. 1998. Electron Microscopy Principles and Techniques for Biologists. $2^{\text {nd }}$ ed. Jones \& Bartlett, Sudbury, MA.

Carvalho-Silva, M. Peperomia Ruiz \& Pav. no Brasil: morfologia e taxonomia do subgênero Rhynchophorum (Miq.) Dahlst. Tese de Doutorado, Instituto de Pesquisas Jardim Botânico do Rio de Janeiro Escola Nacional de Botânica Tropical. 2008.

Dahlstedt, H. 1900. Studien uber sud-und central Amerikanishe Peperomien. Kongliga Svenska Vetenskapsakademiens Handlingar 33(2): 1-218.

da Silva, N. G., Alves, R. J. V.,da Silva Sylvestre, L. Santos, R. B. 2013.Two rediscoveries and one extinction for the flora of Trindade Island, Brazil 1.The Journal of the Torrey Botanical Society 140: 230-235.

Doyle, J. J. \& Doyle, J. L. 1987. A rapid isolation procedure for small quantities of fresh leaf tissue. Phytochemical Bulletin 19: 11-15.

Duarte, R. H. \& Horta, G. C. M. M. 2012. Barth e a ilha da Trindade, 1957-1959. Hist. Cienc.saude - Manguinhos.19:951-968.

Eyre-Walker, A., \& Keightley P. D. 2007. The distribution of fitness effects of new mutations. Nat. Rev. Genet. 8: 610-618. 
Felsenstein, J. 1985. Confidence limits on phylogenies: an approach using the bootstrap. Evolution 39: 779-783.

Frodin, D. G. 2004. History and concepts of big plant genera. Taxon 53: 753-776.

Guimarães, E.F., Carvalho-Silva, M., Monteiro, D., Medeiros, E.S. 2014. Piperaceae in Lista de Espécies da Flora do Brasil. Jardim Botânico do Rio de Janeiro. Disponível em: <http://floradobrasil.jbrj.gov.br/jabot/floradobrasil/FB12609>. Acesso em: 20 Dez. 2014

Griffiths A.J.F., Gelbart W.M., Miller J.H., et al. Modern Genetic Analysis. New York: W.H.Freeman.1999. Disponível em:http://www.ncbi.nlm.nih.gov/books/NBK21248/

Gusmão, L. G. S. 2005. Ilha da Trindade e Arquipélago Martin Vaz. In: Geografia : ensino fundamental e ensino médio: o mar no espaço geográfico brasileiro / coordenação Carlos Frederico Simões Serafim, organização Paulo de Tarso Chaves. - Brasília : Ministério da Educação, Secretaria de Educação Básica, 2005. 304 p. (Coleção explorando o ensino , v. 8).

Hammer, Ø., Harper, D.A.T., Ryan, P.D. 2001. PAST: Paleontological statistics software package for education and data analysis. Palaeontologia Electronica 4(1): 9pp.

Higgins, D.G. \& Sharp, P.M. 1988. CLUSTAL: a package for performing multiple sequence alignment on a microcomputer. Gene 73:237-244

Hilu, K. W. and Liang, H. 1997. The matK gene: sequence variation and application in plant systematics. American Journal of Botany 87: 830-839.

Lodish, H., Baltimore, D., Berk, A., Zipursky, S. L., Matsudaira, P. \& Darnell, J. Molecular Cell Biology. $3^{\text {a }}$ ed. 1995. Scientific American Books.

McMurray,C.T. 2010. Mechanisms of trinucleotide repeat instability during human development. Nat. Rev. Genet. 11:786-799.

Medeiros, E. S.S.. Flora do Parque Estadual do Ibitipoca, Minas Gerais, Brasil -Família Piperaceae. 2006. 45 f. Dissertação. Instituto de Pesquisas Jardim Botânico do Rio de Janeiro/Escola Nacional de Botânica Tropical. Rio de Janeiro, 2006. 
Mullis, K. B. \& Faloona, F. A. 1987. Specific synthesis of DNA in vitro via a polymerase-catalyzed chain reaction. Methods Enzymol. 155: 335-350.

Ronquist, F. \& Huelsenbeck, J. P. 2003. MRBAYES 3: Bayesian phylogenetic inference under mixed models. Bioinformatics 19:1572-1574.

Samain, M.S., Vanderschaeve, L., Chaerle, P., Goetghebeur, P., Neinhuis, C. \& Wanke, S. 2009. Is morphology telling the truth about the evolution of the species rich genus Peperomia(Piperaceae)? Plant Systematics and Evolution, 278: 1-21.

Serafini, T.Z.; França, G.B.D. \& Andriguetto-filho, J.M. 2010. Ilhas oceânicas brasileiras: biodiversidade conhecida e sua relação com o histórico de uso e ocupação humana. Journal of Integrated Coastal Zone Management 10(3): 281301.

Silva, N.G. \& Alves, R.J.V. 2011. The eradication of feral goats and its impact in plant biodiversity - a milestome in the history of Trindade Island, Brazil. Rodriguesia 62(3): 717-719.

Stuessy, T. F., Foland, K., Sutter, J., Sanders, R., Silva, M.. 1984. Botanical and geological significance of potassium-argon dates from the Juan Fernandez Islands. Science. 225: 49-51.

Stuessy, T.F., Jakubowsky, G., Salguero-Gómez, R., Pfosser, M., Schluter, P.M., Fer, T., Sun, B-Y., Kato, H. 2006. Anagenetic evolution in island plants. Journal of Biogeografy 33:1259-1265.

Stuessy, T. F., Takayama, K. López-Sepúlveda, P. \& Crawford, D.J. 2014. Interpretation of patterns of genetic variation in endemic plant species of oceanic islands. Botanical Journal of the Linnean Society 174: 276-288.

Swofford, D. L. 2002. PAUP*. Phylogenetic Analyses using parsimony (*and other methods), version 4.0. Sinauer Associates, Sunderland, Massachussetts.

Symmank, L., Samain, M. S., Smith, J. F., Pino, G., Stoll, A., Goetghebeur, P., Neinhuis, C. \& Wanke, S. 2011. The extraordinary journey of Peperomia subgenus Tildenia (Piperaceae): insights into diversification and colonization patterns from its cradle in Peru to the Trans-Mexican Volcanic Belt. Journal of Biogeography 38: 2337-2349. 
Thiers, B. 2014. Index Herbariorum: A global directory of public herbaria and associated staff. New York Botanical Garden's Virtual Herbarium. http://sweetgum.nybg.org/ih/

USDA, ARS, National Genetic Resources Program.

Germplasm Resources Information Network - (GRIN) [Online Database].

National Germplasm Resources Laboratory, Beltsville, Maryland.

URL: http://www.ars-grin.gov/cgi-bin/npgs/html/taxon.pl?312890 ( acesso em 05 de janeiro de 2015).

Valdebenito, H., Stuessy, T.F \& Crawford, D. J. 1990. Synonyny in Peperomia berteroana (Piperaceae) results in biological disjunction between Pacific and Atlantic Oceans. Brittonia, 42: 121-4.

Valdebenito, H., Stuessy, T.F, Crawford, D. J. \& Silva O.M. 1992. Evolution of Peperomia (Piperaceae) in the Juan Fernandez Islands, Chile. Plant Systematics and Evolution, 182: 107-19.

Wanke, S.; Jaramillo, M.A.; Borsch, T.; Samain, M.S.; Quandt, D. \& Neinhuis, C. 2007. Evolution of the Piperales - matK and trnK intron sequence data reveal lineage specific resolution contrast. Molecular Phylogenetics and Evolution 42: 477-497.

Wanke, S.; Samain, M.S.; Vanderschaeve, L.; Mathieu, G.; Goetghebeur, P. \& Neinhuis, C. 2006. Phylogeny of the genus Peperomia (Piperaceae) inferred from the trnK/matK region (cpDNA). Plant Biology 8: 93-102.

Yuncker, T.G. 1974. The Piperaceae of Brazil-III: Peperomia; taxa of uncertain status. Hoehnea 4: 71-413.

Zwickl, D. J. 2006. Genetic algorithm approaches for the phylogenetic analysis of large biological sequence datasets under the maximum likelihood criterion. Ph.D. dissertation, The University of Texas at Austin. 


\section{CAPÍTULO II}

Peperomia sp. (Piperaceae), uma nova espécie da Ilha da Trindade, Brasil. 


\title{
Peperomia sp. (Piperaceae), uma nova espécie da Ilha da Trindade, Brasil.
}

\author{
Tamara Silva Dantas ${ }^{1}$, Paulo E. A. S. Câmara ${ }^{1}$ e Micheline Carvalho Silva ${ }^{1}$ \\ ${ }^{1}$ Universidade de Brasília, Instituto de Ciências Biológicas, Departamento de Botânica
}

\section{Introdução}

Piperaceae é considerada uma das maiores famílias entre as angiospermas basais. É composta por cinco gêneros, sendo Piper L. e Peperomia Ruiz \& Pav. os mais diversos, tanto no mundo como no Brasil (Guimarães et al. 2009). Peperomia possui distribuição pantropical (Wanke et al. 2006), com ca. de 1600 espécies, sendo que ca. de 1400 espécies ocorrem no neotrópico (Wanke et al. 2006), desde o sul dos Estados Unidos até a Argentina. O gênero está entre os mais ricos em números de espécies (Frodin 2004; Samain et al. 2009) e no Brasil, são aceitas 166 espécies de Peperomia, sendo 103 endêmicas. As espécies são encontradas nas cinco regiões brasileiras, nos domínios fitogeográficos da Amazônia, Caatinga, Cerrado e Mata Atlântica (Guimarães et al. 2014).

Peperomia são ervas predominantemente epífitas, podendo também ser encontradas em fendas de rochas ou no solo e têm preferência por locais úmidos e sombreados (Symmank et al. 2011). São plantas frequentemente suculentas, com filotaxia alterna, verticilada ou oposta, folhas sempre inteiras, geralmente pecioladas, inflorescências em espádices em posição terminal, axilar ou oposta a folha, com flores aperiantadas, dois estames, um ovário, um óvulo, um lóculo e estigma único (Yuncker 1974).

Dalhstedt (1900) dividiu o gênero em nove subgêneros baseado na morfologia do fruto e segundo Yuncker (1974) as espécies brasileiras foram divididas em cinco subgêneros. Wanke et al. (2006, 2007) realizando estudos filogenéticos com Peperomia mostraram que o gênero é monofilético. Estudos de Wanke et al. (2006) e Samain et al. (2009) sobre as relações filogenéticas do gênero apresentam a formação de oito clados monofiléticos. Wanke et al. (2006) incluíram a espécie Peperomia glabella (Sw.) Dietr. no clado nomeado Sphaerocarpidium, sendo este composto pelas espécies do subgênero Sphaerocarpidium (Dahlst.) sensu Dahlstedt (1900). O clado nomeado 
Sphaerocarpidium por Wanke et al. (2006) foi tratado por Samain et al. (2009) como clado Micropiper, já que o subgênero Micropiper (Miq.) Miq. havia sido nomeado erroneamente por Dalhstedt (1990). Mesmo com a adição de novos marcadores no trabalho de Samain et al. (2009) o clado Micropiper permaneceu com a mesma circunscrição.

Peperomia glabella é encontrada na região neotropical (USDA 2015) e no Brasil possui representantes na Mata Atlântica, desde Pernambuco ao Rio Grande do Sul e poucos registros na Amazônia (Guimarães et al. 2014), sendo também é encontrada na Ilha da Trindade. Segundo Alves \& Guimarães (1998) são registradas duas espécies de Peperomia em Trindade: Peperomia beckeri E.F.Guim. \& R.J.V.Alves, considerada endêmica e conhecida apenas pelo material tipo que se encontra no Museu Nacional (herbário R) e P. glabella (Sw.) A. Dietr var. glabella e $P$. glabella var. nigropunctata (Miq.) Dahlst.

A Ilha da Trindade é uma ilha oceânica localizada cerca de $1.200 \mathrm{~km}$ da costa

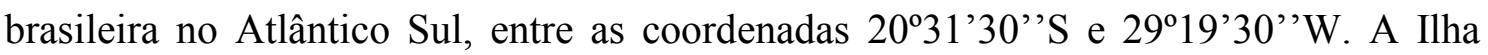
possui $9.28 \mathrm{~km}^{2}$ de superfície e o ponto de maior altitude com $620 \mathrm{~m}$, o Pico do Desejado (Serafini et al. 2010; Alves 1998). Atualmente 60\% da ilha é coberta por vegetação herbácea e menos de $5 \%$ é coberta por vegetação de floresta formando a “floresta nebular de samambaias gigantes" (Alves 1998; Silva \& Alves 2011).

Trindade apresenta uma alto grau de endemismo devido ao isolamento geográfico, cerca de 10\% das plantas vasculares são endêmicas (Alves 1998). Foi observado que as plantas oriundas de Trindade e identificadas como Peperomia glabella apresentavam diferenças morfológicas da P. glabella que ocorre no continente. Estudos morfológicos e genéticos destas plantas (Dantas et al. (não publicado - capítulo I) mostram que a Peperomia que é identificada como $P$. glabella em Trindade não é $P$. glabella e sim um táxon novo e endêmico, Peperomia sp. 


\section{Material e Métodos}

Foram realizadas três expedições à Ilha da Trindade para coleta de material durante o período de dois anos. Os dados apresentados foram baseados em análises de exsicatas de $P$. sp., depositados no herbário UB e R, além de análises de material vivo e observações em campo. Também foram analisadas 200 exsicatas de Peperomia glabella e suas variedades depositadas nos herbários: BHCB, CEN, CEPEC, FLOR, FURB, HRCB, HUCS, HUEFS, IAC, IAN, IPA, MBM, PACA, R, RB, SP, SPSF, UB, VIC e VIES, além dos materiais tipos depositados nos herbários G e NY (siglas segundo Thiers 2014). Análise de material vivo e observações em campo de Peperomia glabella também foram realizadas. Espécies de Peperomia que podem ser confundidas com Peperomia sp. também foram analisadas, P. glabella (Sw.) A. Dietr., P alata Ruiz \& Pav., P. diaphanoides Dahlst. e P. beckeri E.F.Guim. \& R.J.V.Alves. A espécie Peperomia sp. foi reconhecida com base nas diferenças morfológicas e moleculares.

Para o estudo filogenético foi utilizada a metodologia segundo Dantas et al. (não publicado - capítulo I).

\section{Tratamento Taxonômico}

Peperomia sp. T.S. Dantas, M. Carvalho-Silva \& P.S. Câmara, sp. nov. - TIPO: BRASIL. Ilha da Trindade: Ilha da Trindade, 20³0'41'’S, 29¹9'27'’W, alt.: 590 m., 11 Mai 2012, M. Carvalho-Silva 1781 (holótipo: UB!, isótipo NY!, RB! ).

\section{Diagnose}

A Peperomia glabella niger gladulae in anterarum differt.

\section{Descrição}

Ervas, terrestres, estoloníferas com ramos ascendentes,de 5, $1-41 \mathrm{~cm}$ de compr., verdes, carnosos, glabros, coberto por glândulas negras (quando em material seco), nós proeminentes, 0,3 - 1,6 cm compr., nós apicais levemente ciliados, ramos levemente alados. Folhas dos ramos ascendentes alternas espiraladas, ovadas ou obovadas, 1,4 3,3 cm compr., 1,1 - 2,1 cm larg., glabras, verdes a verde-amareladas, levemente discolores, com glândulas negras em ambas as faces, base obtusa a aguda, ápice obtuso, hirsuto; nervação acródroma, nervuras 3, conspícuas; pecíolo levemente ciliado. Folhas dos ramos estoloníferos alternas, obovadas, 0,9-1,3 cm compr., 0,7-1,1 cm larg., 
glabras, verdes, com glândulas negras em ambas as faces, base obtusa, ápice obtuso hirsuto; pecíolo levemente ciliado; nervação acródoma, nervuras 3, conspícuas. Inflorescências em espádice, 1-3 terminais, 5-7,2 cm compr., $1 \mathrm{~mm}$ de diâm., eretas, pedúnculo 0,8-1 cm compr., glabras, verde-amareladas, cobertas por glândulas negras, raque 4-6,2 cm compr., fóveas inconspícuas, brácteas florais ca. $1 \mathrm{~mm}$ diâm., orbiculares, peltadas, inseridas na base da fóvea, coberta com glândulas negras, glabras, flores dispostas laxamente na inflorescência, anteras cobertas por glândulas negras. Frutos 1,2 - 1,5 mm compr., ca. $1 \mathrm{~mm}$ larg., sésseis, estipitado, globosos, castanhos, fosco, coberto por glândulas translúcidas, ápice curto rostrado, estigma no centro do rostro (figura 1). 


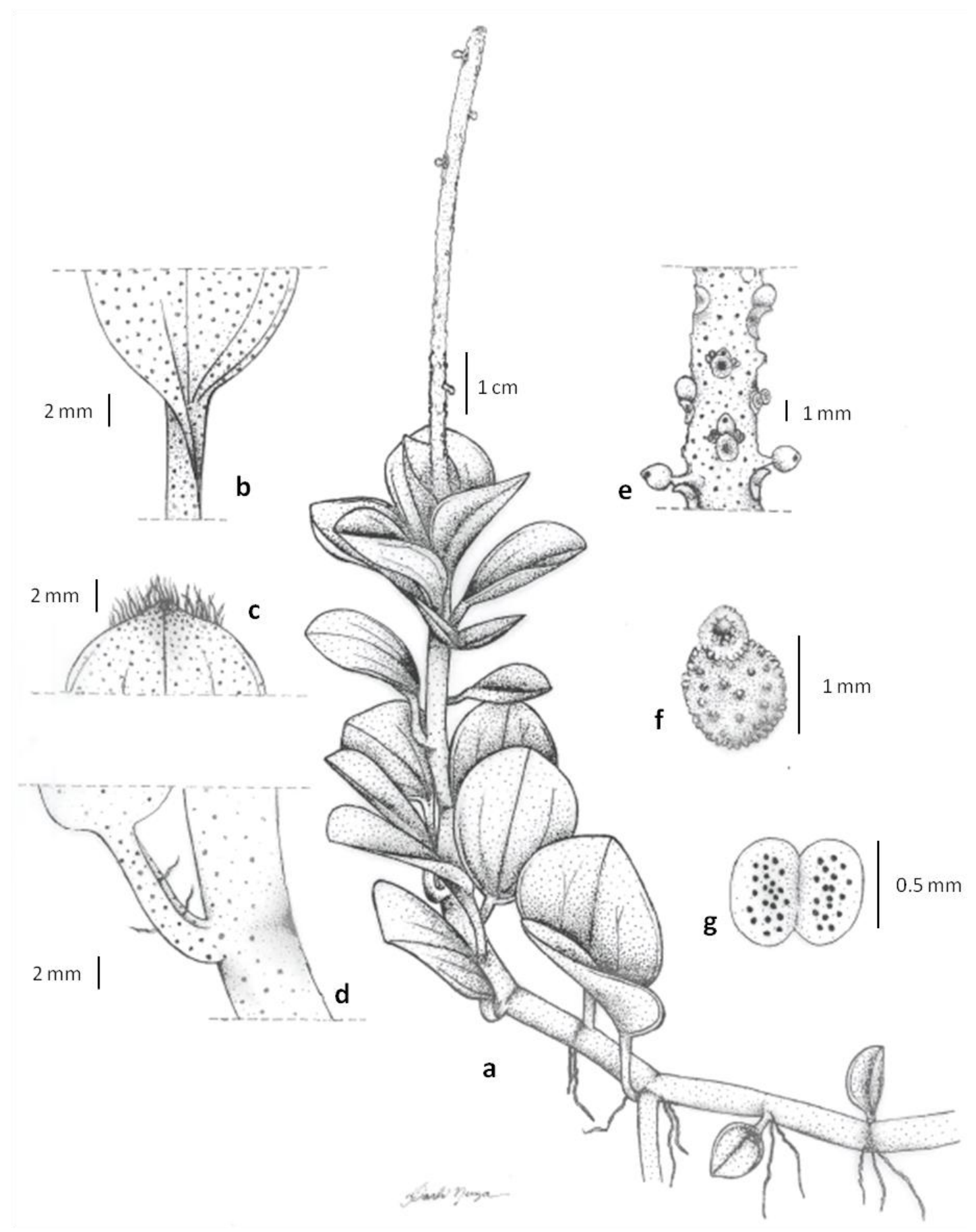

Figura 1. a - g: Peperomia sp. T.S. Dantas, M. Carvalho-Silva e P.S. Câmara. a. hábito. b. base da folha, face adaxial. c. ápice da folha, face adaxial. d. Pecíolo com tricomas esparsos. e. Detalhe da espádice. f. Fruto globoso evidenciando ápice com rostro curto. g. Vista frontal da antera com glândulas negras. 


\section{Distribuição Geográfica e Ecologia -}

Peperomia sp. ocorre apenas na Ilhada Trindade, em regiões de altitudes elevadas (ca. de $600 \mathrm{~m}$ ) na "floresta nebular de samambaias gigantes" (figura 2). Peperomia sp. é frequentemente terrestre, com poucos indivíduos com alguns ramos ascendentes subindo e escorando na base das samambaias gigantes e ocorre principalmente em locais sombreados, debaixo das samambaias gigantes (figura 3). São poucos os indivíduos que ocorrem em local menos sombreado, em áreas abertas na floresta geralmente elas não ocorrem. A espécie foi encontrada com flores e frutos de março a maio, mas foram poucos indivíduos encontrados em fase reprodutiva.

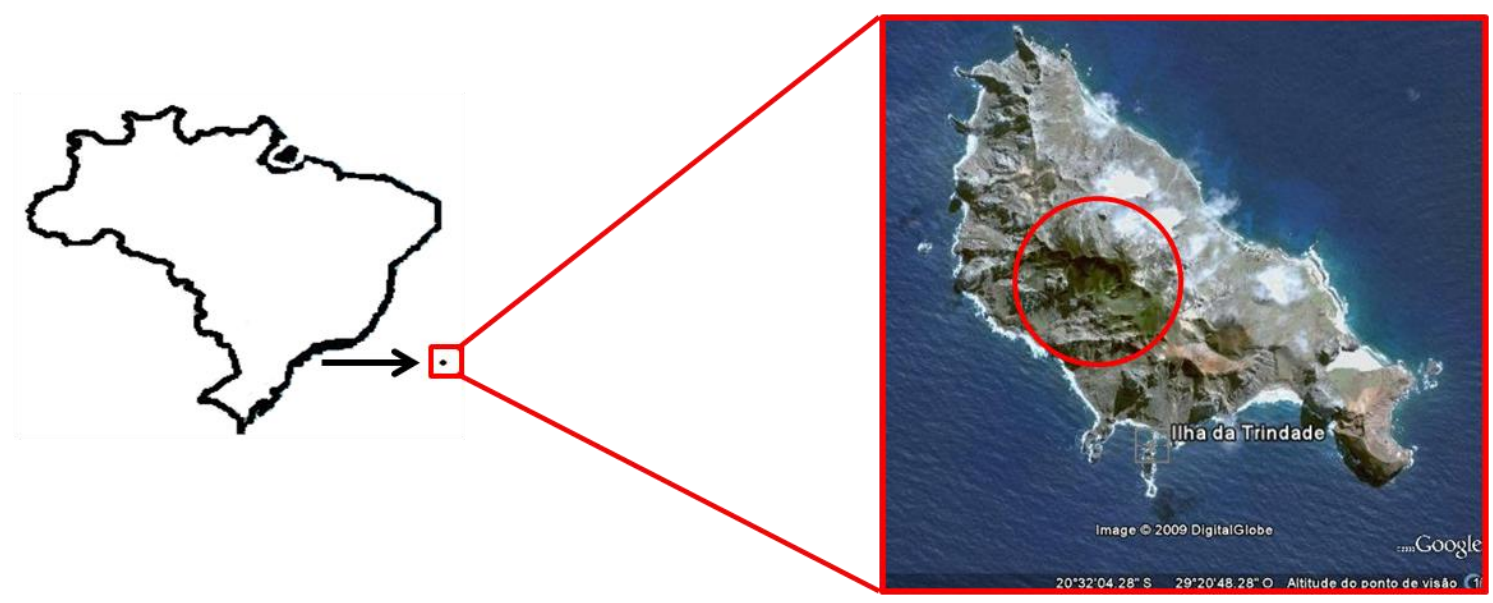

Figura 2. Localização da Ilha da Trindade, em destaque localização da "floresta de samambaias gigantes" encontrada somente em altitudes elevadas.

Embora a espécie ocorra em uma área protegida pela Marinha do Brasil é importante notar que a Ilha como um todo possui área menor que $10 \mathrm{~km}^{2}$, e a espécie é encontrada em um único local, na "Floresta de Samambaias", em uma área inferior a $100 \mathrm{~m}^{2}$, sendo que esta floresta representa menos de $5 \%$ da vegetação da Ilha da Trindade. Assim sendo, sugere-se que a espécie seja considerada Criticamente em Perigo (CR), IUCN (2012). 


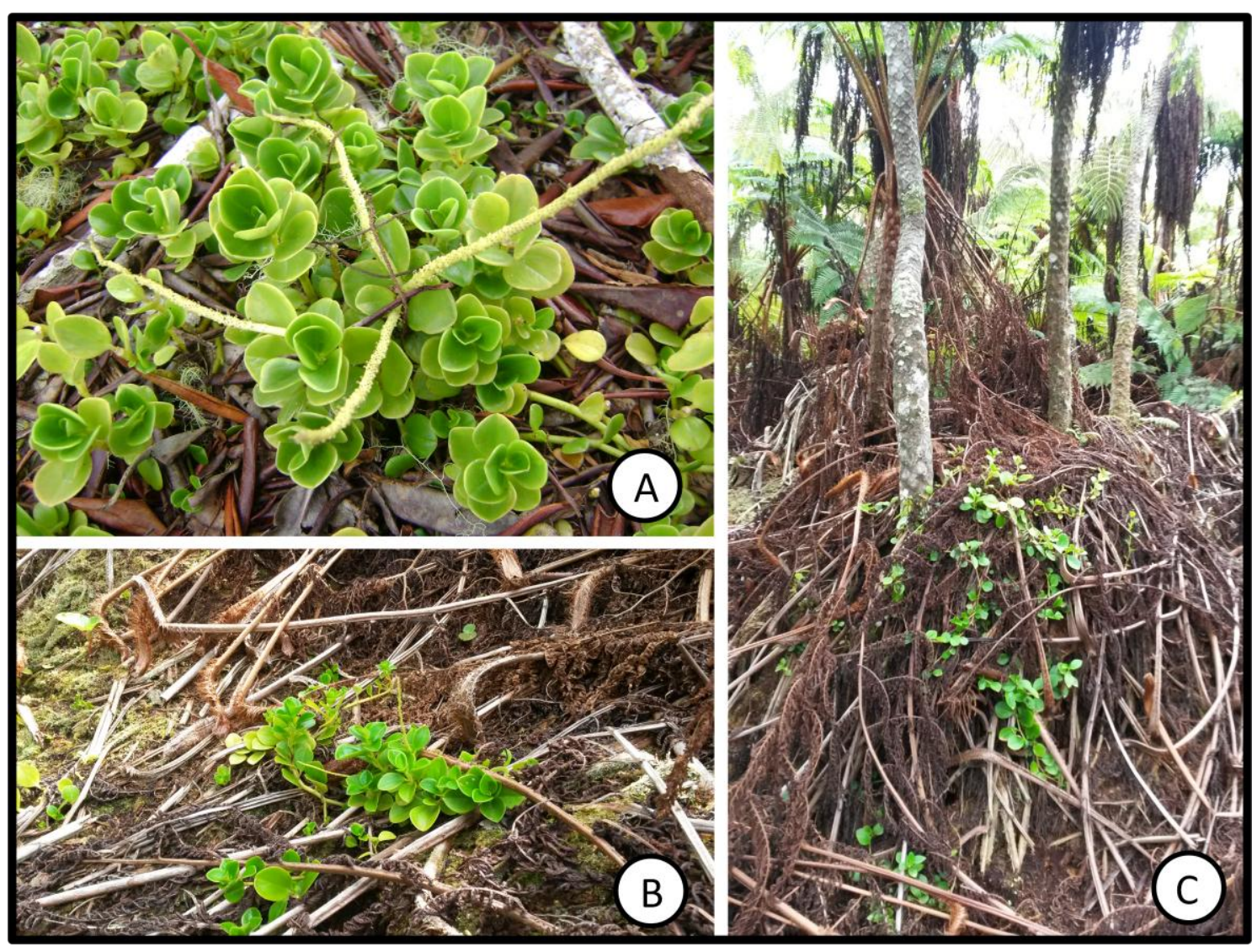

Figura 3. A - C. Peperomia sp. A e B. Hábito terrestre. C. Ocorrência debaixo das samambaias gigantes.

\section{Espécimes adicionais examinados}

BRASIL. Ilha da Trindade, Floresta de Samambaias, 20³0'36' 'S, 29¹9'38' 'W, alt: 513m, 11 Mai 2012, Carvalho-Silva, M. 1787 (UB); Ilha da Trindade, Trilha da Fazendinha, Floresta de Samambaias, 20³0'36'S, 29¹9'38' W, alt: 513m, 11 Mai 2012, Carvalho-Silva, M. 1791 (UB); Ilha da Trindade, Floresta de Samambaias, 20³0’36' S, 29¹9'38'’W, alt: 513m, 11 Mai 2012, Carvalho-Silva, M. 1785 (UB); Ilha da Trindade, Floresta de Samambaias, 20³0’36'’S, 29¹9’38'’ W, alt: 513m, 11 Mai 2012, Carvalho-Silva, M. 1783 (UB);

\section{Observações}

Peperomia sp. é caracterizada pelo hábito terrestre, com folhas ovadas ou obovadas, de ápice hirsuto, entrenós do ápice curtos quando comparados com os entrenós basais. As folhas de filotaxia alterna espiralada e bastante congestas no ápice nos ramos ascendentes e a presença de glândulas negras nas folhas, ramos, inflorescências e principalmente nas anteras, distinguem essa espécie. 
Peperomia sp. pode ser confundida com Peperomia glabella (Sw.) A. Dietr., pela forma e a presença de glândulas negras nas folhas, mas $P$. glabella são ervas epífitas com ramos descendentes e pêndulos, as folhas são frequentemente igualmente distribuídas por toda a planta, não apresentando folhas congestas no ápice, com filotaxia alterna, não sendo espiraladas. As anteras de $P$. glabella são simples sem a presença de glândulas, enquanto Peperomia sp. possui as anteras recobertas por glândulas negras. Quando vivas os nós de P. glabella possuem coloração avermelhadas e em Peperomia sp. são completamente esverdeados.

Peperomia alata Ruiz \& Pav. pode ser confundida com Peperomia sp., devido à presença de ramos levemente alados e o formato das folhas e principalmente quando são encontradas com as folhas menores, porém, P. alata é distinguida de Peperomia sp. por não apresentar glândulas negras em nenhum parte da planta.

Outra espécie que pode ser confundida com Peperomia sp. é Peperomia diaphanoides Dahlst. por apresentarem ramos estoloníferos e ascendentes com as folhas congestas no ápice, e presença de glândulas negras em ambas as faces, mas são diferenciadas por $P$. diaphanoides apresentar folha obovada-lanceolada, elíptica, lanceolada, de tamanho maior, pela face abaxial apresentar coloração avermelhada e por ser uma planta epífita, rupícola e terrestre (Medeiros 2006). A comparação de características morfológicas destas espécies é mostrada na tabela 1. 
Tabela 1. Comparação de características morfológicas de Peperomia sp. e espécies de Peperomia relacionadas, segundo Yuncker (1974), Guimarães e Alves (1998)e Medeiros (2006).

\begin{tabular}{|c|c|c|c|c|c|}
\hline & Peperomia sp. & P. glabella & P. alata & P. diaphanoides & P. beckeri \\
\hline Hábito & Terrestre & Epífita & $\begin{array}{l}\text { Epífita, } \\
\text { rupícola, } \\
\text { terrestre }\end{array}$ & Epífita, & \\
\hline $\begin{array}{l}\text { Ápice da } \\
\text { folha }\end{array}$ & $\begin{array}{l}\text { Ciliado e ciliado } \\
\text { em direção ao } \\
\text { ápice }\end{array}$ & Ciliado & $\begin{array}{l}\text { Ciliado em } \\
\text { direção ao ápice }\end{array}$ & $\begin{array}{l}\text { Ciliado em } \\
\text { direção ao ápice }\end{array}$ & \\
\hline Pecíolo & Ciliado & Ciliado & Não ciliado & Não ciliado & \\
\hline Nós & & $\begin{array}{l}\text { Coloração } \\
\text { avermelhada }\end{array}$ & & & \\
\hline Ramos & $\begin{array}{l}\text { Levemente } \\
\text { alados }\end{array}$ & $\begin{array}{l}\text { Levemente } \\
\text { alados }\end{array}$ & $\begin{array}{l}\text { Levemente } \\
\text { alados }\end{array}$ & Não alado & \\
\hline $\begin{array}{l}\text { Formato da } \\
\text { folha }\end{array}$ & $\begin{array}{l}\text { Ovadas ou } \\
\text { obovadas }\end{array}$ & $\begin{array}{l}\text { Ovadas ou } \\
\text { elípticas- } \\
\text { lanceoladas }\end{array}$ & $\begin{array}{l}\text { Elíptica- } \\
\text { lanceolada, } \\
\text { eliptica }\end{array}$ & $\begin{array}{l}\text { Ovada ou } \\
\text { elíptica-ovada }\end{array}$ & Obovada \\
\hline Filotaxia & $\begin{array}{l}\text { Alternas } \\
\text { espiraladas nos } \\
\text { ramos } \\
\text { ascendentes }\end{array}$ & $\begin{array}{l}\text { Alternas } \\
\text { dísticas por } \\
\text { todo ramo }\end{array}$ & $\begin{array}{l}\text { Alternas dísticas } \\
\text { por todo ramo }\end{array}$ & $\begin{array}{l}\text { Alternas dísticas } \\
\text { por todo ramo }\end{array}$ & Verticilada \\
\hline $\begin{array}{l}\text { Glândulas } \\
\text { negras }\end{array}$ & $\begin{array}{l}\text { Nos ramos, } \\
\text { folhas, } \\
\text { espádices, } \\
\text { anteras }\end{array}$ & $\begin{array}{l}\text { Nos ramos, } \\
\text { folhas, } \\
\text { espádices }\end{array}$ & Não possui & $\begin{array}{l}\text { Presente em } \\
\text { ambas as faces } \\
\text { da folhas }\end{array}$ & $\begin{array}{l}\text { Glândulas } \\
\text { vermelhas } \\
\text { nas anteras }\end{array}$ \\
\hline
\end{tabular}

\section{Discussão}

Segundo Alves \& Guimarães (1998), ocorrem na Ilha da Trindade Peperomia beckeri, P. glabella var. glabella e $P$. glabella var. nigropunctata. P. beckeri é descrita apenas pelo material tipo que está bastante destruído no Museu Nacional (herbário R). Esta espécie é caracterizada pelas folhas 3-4 verticiladas, obovadas com 3,5-4 cm de comprimento, 1,7-2 cm de largura, e glândulas em ambas as faces, espiga terminal, brácteas florais arredondadas, glandulosas e glabras, flores densamente aglomeradas, anteras com glândulas vermelhas e fruto globoso à ovóide. Peperomia beckeri apresenta diversas características que também são comuns à Peperomia sp., sugerindo a primeira vista que esta seria a espécie nova aqui descrita. No entanto, as flores densamente aglomeradas e as folhas 3-4 verticiladas a distingue imediatamente de Peperomia sp. 
De acordo com Alves \& Guimarães (1998), P. beckeri era representada por uma população restrita ao topo de um único pico, coletada em 1965, e não tem sido reencontrada durante outras expedições a mesma localidade, portanto a espécie permanece conhecida apenas pelo material tipo (Alves \& Guimarães 1998; da Silva et al. 2013) e é considerada extinta (da Silva et al. 2013).

Todas as espécies de Peperomia que foram anteriormente encontradas para a IIha da Trindade foram identificadas como P. glabella var. glabella e P. glabella var. nigropuncatata (Alves et al 1998), no entanto os estudos morfológicos e filogenéticos (ainda não publicados) mostram que são espécies diferente. Morfologicamente Peperomia sp. e P. glabella possuem diferenças quanto ao formato das folhas, à filotaxia, à coloração dos nós e a presença ou não de glândulas negras nas anteras, além do hábito ser diferente. Os estudos filogenéticos, realizados com região do trnK/matK e o ITS , mostraram que Peperomia sp. pertence ao clado Micropiper sensu Samain 2009, mesmo clado que P. glabella, mas apenas Peperomia sp. apresenta mutações no trnK/matK (uma transversão e uma inserção de 19 pares de base) com relação às outras Peperomia analisadas. Os cladogramas gerados apenas com trnK/matK mostram a formação de um grupo apenas com as Peperomia sp. (Dantas et al. não publicado capítulo I). Mesmo este clado com suporte baixo as diferenças genéticas e a divergência média interespecífica justificam a separação em duas espécies diferentes (resultados mostrados em Dantas et al, não publicado). Portanto, todo o material que era identificado na Ilha da Trindade como P. glabella var. glabella e P. glabella var. nicropunctata pertence à nova espécie Peperomia sp.

Atualmente só é encontrada Peperomia sp. na Ilha da Trindade, não ocorrendo Peperomia glabella e suas variedades neste local. As plantas são encontradas apenas em regiões de altitude elevada (ca. $600 \mathrm{~m}$ de altitude), na "Floresta Nebular de Samambaias Gigantes" no Pico do Desejado. A biodiversidade de ilhas, geralmente, é bastante particular (Serafini et al. 2010) e o que chama a atenção em Trindade não é a diversidade e sim o número de espécies endêmicas (Gusmão 2005). Sendo Peperomia sp. uma espécie nova e endêmica da Ilha da Trindade. 


\section{Referências Bibliográficas}

Alves, R.J.V. \& Guimarães, E.F. 1998. Piperaceae da Ilha da Trindade. Bradea 8(17): 97-100.

Alves, R.J.V. 1998. Ilha da Trindade e Arquipélago Martin Vaz - Um Ensaio Geobotânico. Serviço de Documentação. Marinha do Brasil Rio de Janeiro. Diretoria de Hidrografia e Navegação.

Dahlstedt, H. 1900. Studien uber sud-und central Amerikanishe Peperomien. Kongliga Svenska Vetenskapsakademiens Handlingar 33, 2: 1-218.

da Silva, N. G.,Alves, R. J. V.,da Silva Sylvestre, L. Santos, R. B. 2013. Two rediscoveries and one extinction for the flora of Trindade Island, Brazil 1 .The Journal of the Torrey Botanical Society, v.140, p. 230-235.

Frodin, D. G. 2004. History and concepts of big plant genera. Taxon 53: 753-776.

Guimarães, E.F. \& Carvalho-Silva, M. 2009. Uma nova espécie e novos nomes em Piper seção Ottonia (Piperaceae) para o Sudeste do Brasil. Hoehnea .36:431-435.

Guimarães, E.F., Carvalho-Silva, M., Monteiro, D., Medeiros, E.S. 2014. Piperaceae in Lista de Espécies da Flora do Brasil. Jardim Botânico do Rio de Janeiro. Disponível em: <http://floradobrasil.jbrj.gov.br/jabot/floradobrasil/FB12609>. Acesso em: 20 Dez. 2014

Gusmão, L. G. S. 2005. Ilha da Trindade e Arquipélago Martin Vaz. In: Geografia : ensino fundamental e ensino médio: o mar no espaço geográfico brasileiro / coordenação Carlos Frederico Simões Serafim, organização Paulo de Tarso Chaves. - Brasília : Ministério da Educação, Secretaria de Educação Básica, 2005. 304 p. (Coleção explorando o ensino , v. 8).

IUCN. 2012. Red List Categories and Criteria: Version 3.1. Second edition. Gland, Switzerland and Cambridge, UK: IUCN. iv + 32pp.

Medeiros, E. S. Flora do Parque Estadual do Ibitipoca, Minas Gerais, Brasil -Família Piperaceae. 2006. 45 f. Dissertação. Instituto de Pesquisas Jardim Botânico do Rio de Janeiro/Escola Nacional de Botânica Tropical. Rio de Janeiro, 2006.

Samain, M.S., Vanderschaeve, L., Chaerle, P., Goetghebeur, P., Neinhuis, C. \& Wanke, S. 2009. Is morphology telling the truth about the evolution of the species rich genus Peperomia(Piperaceae)? Plant Systematics and Evolution, 278,1-21.

Serafini, T.Z., França, G.B.D. \& Andriguetto-filho, J.M. 2010. Ilhas oceânicas brasileiras: biodiversidade conhecida e sua relação com o histórico de uso e ocupação humana. Journal of Integrated Coastal Zone Management 10(3): 281301.

Silva, N.G. \& Alves, R.J.V. 2011. The eradication of feral goats and its impact in plant biodiversity - a milestome in the history of Trindade Island, Brazil. Rodriguesia 62(3): 717-719.

Symmank, L., Samain, M. S., Smith, J. F., Pino, G., Stoll, A., Goetghebeur, P., Neinhuis, C. \& Wanke, S. 2011. The extraordinary journey of Peperomia subgenus Tildenia (Piperaceae): insights into diversification and colonization patterns from its cradle in Peru to the Trans-Mexican Volcanic Belt. Journal of Biogeography 38: 2337-2349. 
USDA, ARS, National Genetic Resources Program. Germplasm Resources Information Network - (GRIN) [Online Database]. National Germplasm Resources Laboratory, Beltsville, Maryland. URL: http://www.ars-grin.gov/cgi-bin/npgs/html/taxon.pl?312890 ( acesso em 05 de janeiro de 2015).

Wanke, S., Samain, M.S., Vanderschaeve, L., Mathieu, G., Goetghebeur, P. \& Neinhuis, C. 2006. Phylogeny of the genus Peperomia (Piperaceae) inferred from the trnK/matK region (cpDNA). Plant Biology 8: 93-102.

Wanke, S., Vanderschaeve, L., Mathieu, G., Neinhuis, C., Goetghebeur, P. \& Samain, M. S. 2007. From Forgotten Taxon to a Missing Link? The Position of the Genus Verhuellia (Piperaceae) Revealed by Molecules. Ann Bot. 2007 June; 99(6): 1231-1238.

Yuncker, T.G. 1974. The Piperaceae of Brazil-III: Peperomia; taxa of uncertain status. Hoehnea 4: 71-413. 


\section{CONCLUSÃO}

As análises morfológicas, morfométricas e de DNA não corroboram a separação de Peperomia glabella (Sw.) A. Dietr. em três variedades, como é descrito para o Brasil. As análises morfológicas e de DNA mostram que a Peperomia que ocorre na Ilha da Trindade, anteriormente identificada como $P$. glabella, na verdade é uma espécie nova e endêmica deste local, sendo que $P$. glabella não ocorre em Trindade e $P$. beckeri foi extinta deste local. A Microscopia Eletrônica de Varredura ainda pode ser utilizada para investigar algumas características morfológicas, que não são vistas no microscópio esteroscópico, como a ornamentação do grão de pólen, a distribuição das glândulas nas folhas e características das glândulas negras que ocorrem nas anteras da Peperomia que ocorre na Ilha da Trindade. 


\section{ANEXOS}

Anexo 1. Material examinado na morfologia de Peperomia glabella e suas variedades e Peperomia sp. São mostrados o nome do táxon, localidade, voucher, herbário e número.

Peperomia glabella Bahia, Caitité, Mendes, M.S. 562, et al., (BHCB 128095). Peperomia glabella Bahia, Ilhéus, Hage, J. L. 1562, (IPA 44339). Peperomia glabella Bahia, Ilhéus, R. P. Belém e M. Magalhães 659 (UB 31632). Peperomia glabella Bahia, Ilhéus, R. P. Belém e M. Magalhães 509, (UB 31633). Peperomia glabella var. glabella Bahia, Feira de Santana, L. R. Noblick n³ 3110, (HUEFS 03266). Peperomia glabella var. nervulosa Bahia, Município de Ilhéus, J. L. Hage, T. S. Santos \& S. G. da Vinha 502, (HUEFS 03043/CEPEC). Peperomia glabella Bahia, Ilhéus, J. L. Hage 1992 \& H. S. Brito (VIES 1167). Peperomia glabella var. glabella Bahia, Almadina, Raimundo S. P. 1030 (RB 8078). Peperomia glabella var. glabella Bahia, Feira de Santana, van den Berg, C. 884, et al. (HUEFS 69721). Peperomia glabella Rio de Janeiro, Jesus Bania 81, (R 170579). Peperomia glabella Rio de Janeiro, entre Lídice e Angra dos Reis, Z. A. Trinta 879 \& E. Fromm 1955, (R 115802). Peperomia glabella Rio de Janeiro, Teresópolis, Y Vidal, II 5138 (912), (R 108318). Peperomia glabella Rio de Janeiro, Madalena, Luiz Emggdio 1213, (R 103741). Peperomia glabella Rio de Janeiro, Teresópolis, Bertha Lutz, (R 86590). Peperomia glabella Rio de Janeiro, Serra dos Órgãos, Luetzelburg 6473, (R 52011). Peperomia glabella Rio de Janeiro, Serra dos Órgãos, Saldanha 7309, (R 52003). Peperomia glabella var. nudipetiolata. Rio de Janeiro, Serra dos Órgãos, E. Ule 4373, (R 38929). Peperomia glabella var. nigropunctata Rio de Janeiro, Teresópolis, J. A. Lombardi 8417 \& Taxonomia de Campo 2011 ( $\mathrm{n}^{\circ}$ caderno de campo: 341), (HRCB 55372). Peperomia glabella Rio de Janeiro, Teresópolis, Vermelho 28 (Araújo, D.; Lautert, M.; Lopes, N.; Moreira, S. N. \& Lombardi, J. A.), (HRCB 58912). Peperomia glabella Rio de Janeiro, Angra do Reis, Fábio de Barros 2894, (SP 276517). Peperomia glabella var. glabella Rio de Janeiro, Serra do Itatiaia, P. Dusen 760, (R 28351). Peperomia glabella var. nigropunctata Rio de Janeiro, Nova Iguaçu, L. C. Giordano, 2617 et al , (SP 392670). Peperomia glabella var. nigropunctata Rio de Janeiro, Bonnet, A. 17, (RB 556696). Peperomia glabella Paraná, Boa Vista (mun. Guaratuba), G. Hatschbach 48551, (PACA 67911). Peperomia glabella Paraná, Município de Antonina, Ricardo Callejas, Gert Hatschbach \& Clovis Ramos, 1810, (PACA 70847). Peperomia glabella Paraná, município de Morretes, G. Hatschbach 49854, (HUCS 22508). Peperomia glabella Paraná, Guaratuba, P. L. 
Krieger, 11057, (VIC 25477). Peperomia glabella Paraná, Paranagua, Ilha no Mel, R. M. Britez 01040, (FUEL 09904). Peperomia glabella Paraná, Guaratuba, P. L. Krieger, 10999, (CESJ). Peperomia glabella var. nervulosa Paraná, Ipiranga, P. Dusen, R 39021. Peperomia glabella var. nervulosa Paraná, Ipiranga, P. Dusen, (R 39019). Peperomia glabella Paraná, mun. Antonina, G. Hatschbach 32975, (BOTU 10470). Peperomia glabella Santa Catarina, Joinville, Schuvacke, ( $\mathrm{R}$ 28331). Peperomia glabella Santa Catarina, Município de Ibirama, L.B. Smith \& R. Klein 7539, (R 170578). Peperomia glabella Santa Catarina, Município de Itajaí, L. B. Smith \& R. Klein 7293, (R 170575). Peperomia glabella Santa Catarina, mun. Florianópolis, F. A. Silva F., Ma Leonor Souza \& Daniel B. Falkenberg 208, (PACA 113273/FLOR 27632). Peperomia glabella Santa Catarina, Sombrio p. Araranguá, R. Reitz 1200, (PACA 31854). Peperomia glabella Santa Catarina, Brusque, R. Reitz 5065, (PACA 54357). Peperomia glabella var. nudipetiolata Santa Catarina, Ibirama, R. Klein 684, (PACA 65329). Peperomia glabella var. nervulosa Santa Catarina, Vargem do Macário, A. Bresolin 387, (PACA 67493/FLOR 5267). Peperomia glabella var. glabella Santa Catarina, Florianópolis, A. Korte 5628, (FLOR 33378/FURB 32986). Peperomia glabella Santa Catarina, Pontal do Daniela, (mun.) Florianópolis, M. Leonor Souza, M. Regina Sá, M. Fronza \& Ana C. Araújo 959, (PACA 70192/FLOR 17943/HUCS 6519/PEL 13667). Peperomia glabella var. nervulosa Santa Catarina, R. M. Klein \& A. Bresolin 10560, (FLOR 5337). Peperomia glabella Santa Catarina, Blumenau, D. B. Falkenberg 3803, (FLOR 16779). Peperomia glabella Santa Catarina, Florianópolis, D. B. Falkenberg, M. L. Souza \& A. C. Araújo 4783, (FLOR 17968). Peperomia glabella Santa Catarina, mun. Ilhota, D. B. Falkenberg 3583, (FLOR 16363). Peperomia glabella Santa Catarina, Florianópolis, D. B. Falkenberg, Amaral, Bedin et al 6090, (FLOR). Peperomia glabella Santa Catarina, Florianópolis, T. B. Guimarães \& Daniel de Barcellos Falkenberg 1106, (FLOR 35373). Peperomia glabella Santa Catarina, Florianópolis, T. B. Guimarães \& Daniel de Barcellos Falkenberg 453, (FLOR 35374). Peperomia glabella Santa Catarina, Blumenau, D. B. Falkenberg 3806, (FLOR 16776). Peperomia glabella var. nervulosa Santa Catarina, Sanga da Areia, Reitz \& Klein 9018, (FLOR 168). Peperomia glabella var. nervulosa Santa Catarina, Cordeiros, Itajaí, Reitz \& Klein 9176, (FLOR 189). Peperomia glabella Santa Catarina, Florianópolis, T. B. Guimarães \& D. B. Falkenberg 701, (FLOR 35375). Peperomia glabella Santa Catarina, Florianópolis, T. B. Guimarães \& D. B. Falkenberg 782, (FLOR 35372). Peperomia cf. glabella var. glabella Santa Catarina, Blumenau, L. A. 
Funez 1204, (FURB 39548). Peperomia cf. glabella var. glabella Santa Catarina, Blumenau, L. A. Funez 1012, (FURB 39201). Peperomia glabella var. glabella Santa Catarina, Taió, M. Verdi, E. Caglioni \& E. M. Martins 5317, (FURB 30625). Peperomia glabella var. glabella Santa Catarina, Joinville, A Korte 5038, (FURB 33016). Peperomia glabella var. glabella Santa Catarina, Rio do Campo, A. Korte \& A. Kniess 1967, (FURB 22094). Peperomia glabella var. glabella Santa Catarina, Mirim Doce, A. Korte \& A. Kniess 1549, (FURB 20883). Peperomia glabella var. glabella Santa Catarina, Biguaçu, T. J. Cadorin, S. M. Clemes, C. P. L. Oliveira \& E. Boing 450, (FURB 16344). Peperomia cf. glabella var. glabella Santa Catarina, Joinville, S. Dreveck \& F. E. Carneiro 1170, (FURB 15754). Peperomia glabella var. glabella Santa Catarina, Presidente Nereu, A. Korte \& A. Kniess 489, (FURB 15513). Peperomia glabella var. glabella Santa Catarina, Blumenau, A. Stival-Santos, E. Legal \& S. Silveira 877, (FURB 14132). Peperomia glabella var. glabella Santa Catarina, Curitibanos, Verdi, M. \& Dreveck, S. 324, (FURB 8020). Peperomia glabella var. glabella Santa Catarina, São Francisco do Sul, Gasper, A. L. 431, (FURB 5013). Peperomia cf. glabella var. glabella Santa Catarina, Porto Belo, J. L. Schmitt, E. Caglioni, S. Andrade \& C. Cristofolini 2905, (FURB 29400). Peperomia glabella var. glabella Santa Catarina, Morro Grande, L. Schmitt, E. Caglioni, S. Andrade \& C. Cristofolini 2286, (FURB 26272). Peperomia glabella Santa Catarina,Guabiruba, A. Stival-Santos, E. Legal \& S. Silveira 1109, (FURB 16160). Peperomia glabella Santa Catarina, Biguaçu, T. J. Cadorin, S. M. Clemes, C. P. L. Oliveira \& E. Boing 422, (FURB 16031). Peperomia glabella var. glabella Santa Catarina, Palhoça, A. Korte 5315, (FURB 32995). Peperomia glabella var. glabella Santa Catarina, Corupá, 26J. L. Schmitt 3214, (FURB 35134). Peperomia glabella var. glabella Santa Catarina, Major Gercino, A. Korte \& A. Kniess 4595, (FURB 32039). Peperomia glabella var. glabella Santa Catarina, Pomerode, T. J. Cadorin 3319, (FURB 36585). Peperomia glabella var. glabella Santa Catarina, Siderópolis, M. Verdi, R. P. Hasckel \& G. Klemz 2344, (FURB 12752). Peperomia glabella var. glabella Santa Catarina, Presidente Nereu, A. Korte \& A. Kniess 463, (FURB 15322). Peperomia glabella Santa Catarina, Orleans, J. L. Schmitt, E. Caglioni, S. Andrade \& C. Cristofolini 2858, (FURB 27327). Peperomia glabella var. glabella Santa Catarina, Angelina, A. Stival-Santos, E. Legal \& S. Silveira 2617, (FURB 26011). Peperomia glabella var. glabella Santa Catarina, São Bento do Sul, T. J. Cadorin, S. M. Clemes \& C. P. L. Oliveira 596, (FURB 17508). Peperomia glabella Santa Catarina, Curitibanos, M. Verdi, S. Dreveck \& M. B. Godoy 289, (FURB 
10098). Peperomia glabella Santa Catarina, Praia Grande, J. L. Schmitt, E. Caglioni, S. Andrade \& C. Cristofolini 2797 (FURB 27258). Peperomia glabella var. glabella Santa Catarina, Blumenau, A. Stival-Santos, M. Verdi \& Dreveck 780, (FURB 13766). Peperomia glabella Santa Catarina, Papanduva, A. L. de Gasper 1716, (FURB 10126). Peperomia glabella Santa Catarina, Campo Alegre, M. Verdi, S. Dreveck \& M. B. Godoy 134, (FURB 10097). Peperomia glabella var. glabella Santa Catarina, São Bento do Sul, T. J. Cadorin, S. M. Clemes \& C. P. L. Oliveira 595, (FURB 17502). Peperomia glabella var. glabella Santa Catarina, Rodeio, A. Korte \& A. Kniess 2419, (FURB 23785). Peperomia glabella var. glabella Santa Catarina, Orleans, J. L. Schmitt, C. Cristofolini \& E. Caglioni 778, (FURB 18040). Peperomia glabella Santa Catarina, José do Cerrito, M. Verdi \& F. E. Carneiro 498, (FURB 9930). Peperomia glabella var. glabella Santa Catarina, Taió, J. L. Schmitt, E. Caglioni, S. Andrade \& C. Cristofolini 1506, (FURB 20709). Peperomia glabella var. glabella Santa Catarina, Joinville, T. J. Cadorin, H. F. Uller \& C. P. L. Oliveira 837, (FURB 17919). Peperomia glabella var. glabella Santa Catarina, Blumenau, T. J. Cadorin, B. Grosch, R. Zimmermann \& C. P. Lopes 1226, (FURB 19828). Peperomia glabella var. glabella Santa Catarina, Indaial, A. Stival-Santos 1312, (FURB 18081). Peperomia glabella var. glabella Santa Catarina, Siderópolis, J. L. Schmitt, C. Cristofolini \& E. Caglioni 626, (FURB 18071). Peperomia glabella var. glabella Santa Catarina, Morro Grande, J. L. Schmitt, C. Cristofolini \& E. Caglioni 876, (FURB 18060). Peperomia glabella var. glabella Santa Catarina, Rio do Sul, Fundo A. Korte \& A. Kniess 1411, (FURB 18006). Peperomia glabella var. glabella Santa Catarina, Blumenau, T. J. Cadorin, S. M. Clemes \& C. P. L. Oliveira 389, (FURB 17944). Peperomia glabella var. glabella Santa Catarina, Morro Grande, M. Verdi, A. L. Tomazi \& G. Klemz 2866, (FURB 15330). Peperomia glabella var. glabella Santa Catarina, Presidente Nereu, J. L. Schmitt, C. Cristofolini, S. Andrade \& E. Caglioni, 359, (FURB 15308). Peperomia glabella var. glabella Santa Catarina, Garuva, J. L. Schmitt, T. J. Cadorin \& A. L. de Gasper 84, (FURB 15031). Peperomia glabella var. glabella Santa Catarina, Botuverá, CinemaT. J. Cadorin, J. L. Schmitt \& E. Caglioni 228, (FURB 14989). Peperomia glabella var. glabella Santa Catarina, Presidente Nereu, A. Korte \& A. Kniess 380, (FURB 14954). Peperomia glabella var. glabella Santa Catarina, Blumenau, T. J. Cadorin, J. L. Schmitt \& A. L. de Gasper 74, (FURB 14177). Peperomia glabella Santa Catarina, Orleans, M. Verdi \& A. L. de Gasper 2195, (FURB 12442). Peperomia glabella var. glabella Santa Catarina, Porto Belo, T. J. Cadorin, J. L. Schmitt \& A. L. 
de Gasper 84, (FURB 14160). Peperomia glabella var. glabella Santa Catarina, Grão Pará, M. Verdi, G. Klemz \& J. F. Torres 2532, (FURB 13921). Peperomia glabella var. glabella Santa Catarina, Florianópolis, T. J. Cadorin, B. Grosch, R. Zimmermann \& C. P. Lopes 1377, (FURB 20779). Peperomia glabella var. glabella Santa Catarina, Porto Belo, J. L. Schmitt, E. Caglioni, S. Andrade \& C. Cristofolini 837, (FURB 20063). Peperomia glabella var. glabella Santa Catarina, Itapoá, Saí A. Korte 4993, (FURB 32803). Peperomia glabella var. glabella Santa Catarina, Florianópolis, T. J. Cadorin, B. Grosch, R. Zimmermann \& C. P. Lopes 1481, (FURB 22502). Peperomia glabella Santa Catarina, Joinville, Reitz \& Klein 5605, (SP 64359). Peperomia glabella Santa Catarina, Urubicí, J. Mattos 12025, (SP 114007). Peperomia glabella Santa Catarina, Urubicí, J. Mattos 12145, (SP 118389). Peperomia glabella Ceará, Saldanha 8091, (R 52006). Peperomia glabella Ceará, Dias da Rocha, (SP 7555). Peperomia glabella Ceará, Serra do Baturité,-, (UB 31634). Peperomia glabella var. nervulosa Amapá, Rio Iaue, H. S. Irwin \& L. Y. Th. Westra 47751, (R 114549/IAN 116433/SP79362). Peperomia glabella var. nervulosa Amapá, Rio Jarí, W. A. Egler e H. S. Irwin, (IAN 116429). Peperomia glabella var. nervulosa Amapá, Rio Araguari, J. M. Pires, Wm. Rodrigues e G. C. Irvine, (IAN 113799/UB34842). Peperomia glabella var. nervulosa Amapá, Rio Jarí, W. A. Egler e H. S. Irwin, (IAN 113294). Peperomia glabella Amapá, Oiapoque. Souza M. A. D de 1754, (IAN 182095). Peperomia glabella var. nervulosa Amapá, Oiapoque, R. L. Fróes 26756 , (IAN 59907). Peperomia glabella var. nervulosa Amapá, Rio Oiapoque, H. S. Irwin, e L. Y. Th. Westra, (IAN 108928). Peperomia glabella var. nervulosa Amapá, Rio Oiapoque, H. S. Irwin, e L. Y. Th. Westra, (IAN 108971). Peperomia glabella var. nervulosa Amapá, Rio Oiapoque, H. S. Irwin, J. M. Pires e L. Y. Th. Westra, (IAN 109147). Peperomia glabella Amapá, Rio Oiapoque. H. S. Irwin, J. M. Pires e L. Y. Th. Westra, (IAN 109283/UB34843). Peperomia glabella var. nervulosa Amapá, Rio Oiapoque, H. S. Irwin, J. M. Pires e L. Y. Th. Westra, (IAN 109421). Peperomia glabella Amapá, Rio Oiapoque. H. S. Irwin, (UB 34844). Peperomia glabella Amapá, Estação Ecológica Ilha de Maracá. D. B. Falkenberg 4742, (FLOR 18003). Peperomia glabella Amazonas, Rio Demeni, G.T. Prance, J.R. Steward, J. F. Ramos \& L.G. Farias, (R 170571). Peperomia glabella Amazonas, Rio Jarí, Nilo Silva, (IAN 127573). Peperomia glabella Rondônia, entre Maitá e vila indígena Paramiteri, G. T. Prance, W. C. Steward, F. P. Harter, J. F. Ramos, W. S. Pinheiro \& O. P. Monteiro, (R 170572). Peperomia glabella Rondônia, Rio Mucajaí, G. T. Prance, W. C. Steward, J. F. Ramos \& O. P. Monteiro, (R 170573). 
Peperomia glabella Rondônia, próximo de Auaris, G. T. Prance, J. R. Steward, J. F. Ramos \& L. G. Farias, (R 170576). Peperomia glabella Rondônia, Rio Mucajaí, G. T. Prance, W. C. Steward, J. F. Ramos \& O. P. Monteiro, (R 170574). Peperomia glabella Rio Jamari, J. M. Pires 9952, (IAN 118244/UB34841). Peperomia glabella Rio Grande do Sul, Morrinhos do Sul J. A. Jarenkow \& M. Sobral 2931, (PEL 14787). Peperomia glabella var. glabella Rio Grande do Sul, Mun. De Mostardas, R. Wasum 4401, (HUCS 32821). Peperomia glabella var. glabella Rio Grande do Sul, Mun. De Mostardas M. Sartori 271, (HUCS 32286). Peperomia glabella var. glabella Rio Grande do Sul, Mun. De Mostardas R Wasum 4391, (HUCS 32708). Peperomia glabella Rio Grande do Sul,Arroio do Sal, M. S. Marchioretto, J. L. Schmitt, D. Becker, S. Cunha, (PACA 109152). Peperomia glabella Rio Grande do Sul,Arroio do Sal, M. S. Marchioretto, A. P. U. Lippert, M. G. Staudt. D. Becker, S. Cunha, (PACA 109167). Peperomia glabella var. glabella Rio Grande do Sul,Arroio do Sal, Machado M. 601 \& Aona L. Y. S., (HUEFS 104927). Peperomia glabella Rio Grande do Sul,Vila Manresa p, Porto Alegre, B Rambo SJ., (PACA 29454). Peperomia glabella Rio Grande do Sul,Vila Manresa p, Porto Alegre, B Rambo SJ., (PACA 1259). Peperomia glabella Rio Grande do Sul, Vila Manresa p, Porto Alegre, B Rambo SJ., (PACA 38543). Peperomia glabella Rio Grande do Sul,Morro do Osso p Porto Alegre, B. Rambo SJ., (PACA 41534). Peperomia glabella Rio Grande do Sul, Morro Santana p. Porto Alegre, B. Rambo SJ., (PACA 42036). Peperomia glabella Rio Grande do Sul, Faz. Do Arroio p. Osorio, B. Rambo SJ., (PACA 45159). Peperomia glabella Rio Grande do Sul, Fortaleza p. Montenegro, B. Rambo SJ., (PACA 54128). Peperomia glabella Rio Grande do Sul,Torres, B. Rambo SJ., (PACA 56495). Peperomia glabella Rio Grande do Sul, Montenegro, Camargo 1790, (PACA 62382). Peperomia glabella Rio Grande do Sul, Arroio do Sal, A. P. U. Lippert, M. G. Staudt. D. Becker, S. Cunha, (PACA 109171). Peperomia glabella Rio Grande do Sul, Mun. Torres, Daniel B.Falkenberg 6053, (FLOR 22989). Peperomia glabella var. glabella Rio Grande do Sul,Mun. De Mostardas L. Crippa 131, (HUCS 35743/FURB 39813). Peperomia glabella var. glabella Rio Grande do Sul, Mun. De Mostardas, R. Wasum 4401, (RB 508053). Peperomia glabella Pará, Belém. J. M Pires, (IAN 144517). Peperomia glabella Pará, Antônia Lemos, G. A. Black 48-2991, (IAN 36893/IAC 13149). Peperomia glabella Minas Gerais, Bom Jesus da Madeira, M. G. Bovini 1596; C de Paula; A Bittencourt \& R. Bortoluzzi, (VIC 23024). Peperomia glabella Minas Gerais, Buenópolis, T. E. Almeida $n^{\circ}$ 880; G Heringer, D. S. Lara \& A. C. V. da Costa, 
(BHCB107219/HUEFS). Peperomia glabella Espírito Santo, Cariacica, Martins, G. H. 125, (VIES 12823). Peperomia glabella Espírito Santo,Linhares, Pereira O. J. 59486 \& Assis A. M., (VIES 10134). Peperomia glabella São Paulo, Município de Mairiporã, J. A. Pastore, F. A. R. D. P. Arzolla \& J. R. dos Santos 1316, (SPSF 34998). Peperomia glabella São Paulo,Município de Barra do Chapéu, R. T. Polisel 480. R. C. Souza \& N. M. Ivanauskas, (SPSF 40770). Peperomia glabella São Paulo,Capital (Chácara de Morrinhos), B. Pickel 4503, (IPA 9183). Peperomia glabella var. glabella São Paulo,Sete Barras, Almeida-Scabbia et al. Coleção Saibadela 861, (HRCB 21530). Peperomia glabella var. nigropunctata São Paulo,São Miguel Arcanjo, Kinoshita, L. S. 246; Urbanetz, C.; Farah, F. T.; Obando-Polo, S. H., (SPSF 034488). Peperomia glabella São Paulo,Estação Experimental Borácea. A. S. Lima, L da Silva, (IAC 5865). Peperomia glabella São Paulo, Pariquera-açu, R. B. Torres et al. 514, (IAC 36685). Peperomia glabella São Paulo, Município de Caraguatatuba, G. L. Esteves, R. S. Bianchini, F. Pinheiro, F. Bonfim, F. O. Souza, L. T. Bopp e M. Sugiyama 2732, (SPSF 028905). Peperomia glabella var. glabella São Paulo,Município de Ubatuba, A. Furlan et al. $\mathrm{n}^{\circ}$ 994, (HUEFS 178688/BHBC 003324). Peperomia glabella São Paulo, Município de Itataré, V.C. Souza, J. P. Souza, V. R. Scalon, A. Astorino 10624, (SP). Peperomia glabella São Paulo,Município de Piraju, A. Rapini, E. L. M. Catharino \& W. Ribeiro 156, (SP). Peperomia glabella São Paulo,Brotas, S. A. Nicolau, T. C. Moreira, D. S. Azevedo, T. C. Campello, P. Trovarelli, A. L. da Conceição, A. N. M. Deus \& J. M. de Oliveira 3220, (SP). Peperomia glabella São Paulo, Brotas, S. A. Nicolau, J. C. Nicolau, \& W. de Lima 3232, (SP). Peperomia glabella São Paulo, Ilhabela, A. Rapini, S. L. Proença \& M. Kirizawa 38, (SP). Peperomia glabella São Paulo,Ubatuba, H. F. Leitão Filho, R. R. Rodrigues, E. L. Borba, Ch. Faivre, I. M. Bortolloto, R. B. Cardamone, K. H. Borges, número: 34350, (UEC). Peperomia glabella São Paulo, Munic. Sete Barras, M.L. Kawasaki, M. Kirizawa \& M. Sugiyama 657, (SP). Peperomia glabella São Paulo, Município de Cunha, C. B. Costa, M. Kirizawa \& A. Rapini 186, (SP 292172). Peperomia glabella São Paulo, Biritiba Mirim, A. Custodio Filho 1898, (SP). Peperomia glabella São Paulo, Cananéia, D. A. De Grande, E. A. Lopes 239, (SP 159780). Peperomia glabella São Paulo, Município de Caraguatatuba, G. L. Esteves, R. S. Bianchini, F. Pinheiro, F. Bonfim, F. O. Souza,L. T. Bopp \& M. Sugiyama 2732, (SP 350698). Peperomia glabella São Paulo, Salesópolis, M. Kuhlmann 2014, (SP 58608). Peperomia glabella São Paulo, Ilha dos Alcatrazes, Luederwaldt \&Fonseca, (SP 12622). Peperomia glabella São Paulo, 
Miracatú, J. Mattos 13842, (SP 118374). Peperomia glabella São Paulo, Município de Peruíbe, V. C. Souza, J. P. Souza et al 9268, (SP 288848). Peperomia glabella var. glabella São Paulo, Município de Mairiporã, F. A. R. D. P. Arzolla, J. A. Pastore, \& J. R. dos Santos 868, (SPSF 34981). Peperomia, Ilha da Trindade, Floresta de Samambaias, Dantas, T. S. 110, (UB). Peperomia, Ilha da Trindade, Floresta de Samambaias, Dantas, T. S. 111, (UB). Peperomia, Ilha da Trindade, Floresta de Samambaias, Dantas, T. S. 112, (UB.) Peperomia, Ilha da Trindade, Carvalho-Silva, M. 1781, (UB). Peperomia, Ilha da Trindade, Floresta de Samambaias, Carvalho-Silva, M. 1787 (UB). Peperomia, Ilha da Trindade, Floresta de Samambaias, Carvalho-Silva, M. 1783, (UB). Peperomia, Ilha da Trindade, Floresta de Samambaias, Carvalho-Silva, M. 1791, (UB). Peperomia, Ilha da Trindade, Floresta de Samambaias, Carvalho-Silva, M. 1785, (UB). Peperomia glabella -,-,-,(R 28290). Peperomia glabella Jamaica, Montanhas Jonh Grow, T. G. Yuncker 18115, (R 108384). Peperomia glabella Panamá, Lago Gatun, Ilha Barro Colorado, Paul C. Hutchison \& J. Kenneth Wright 2918, (R 117016). Peperomia glabella var. nudipetiolata Equador, Prov. Napo-Pastaza: Borja (Virgilio Dávila), Gunnar Harling, (R 170570). Peperomia glabella Equador, PROV. NAPO- PASTAZA: Tena, estrada para Archidona, Gunnar Harling, (R 170577). Peperomia glabella México, Edo. Veracruz, Mun. Teocelo. M. Nee 23564, (SP 212285). 